\title{
Current freezing and thawing scenarios employed by North Atlantic fisheries: Their potential role on Newfoundland and Labrador's northern cod (Gadus morhua) fishery
}

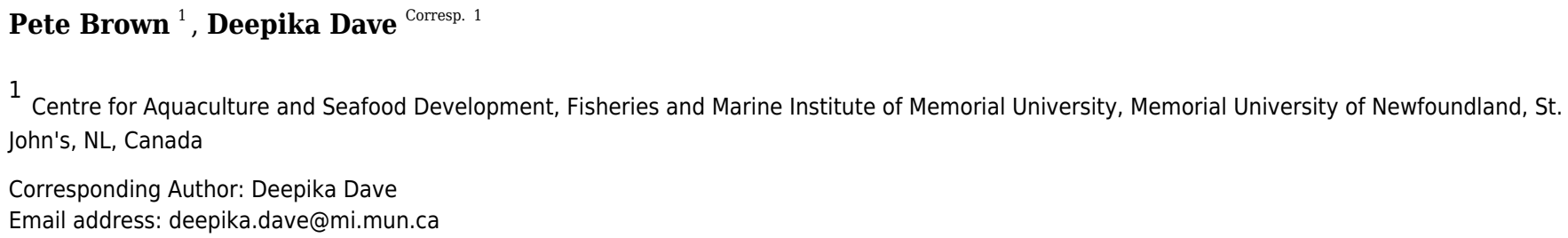

Seafood is very perishable and can quickly spoil due to three mechanisms: autolysis, microbial degradation, and oxidation. Primary commercial sectors within the North Atlantic fisheries include demersal, pelagic, and shellfish fisheries. The preservation techniques employed across each sector can be relatively consistent; however, some key differences exist across species and regions to maintain product freshness. Freezing has long been employed as a preservation technique to maintain product quality for extended periods. Freezing allows seafood to be held until demand improves and shipped long distances using lower-cost ground transportation while maintaining organoleptic properties and product quality. Thawing is the opposite of freezing and can be applied before additional processing or the final sale point. However, all preservation techniques have limitations, and a properly frozen and thawed fish will still suffer from drip loss. This review summarizes the general introduction of spoilage and seafood spoilage mechanisms and the latest preservation techniques in the seafood industry, focusing on freezing and thawing processes and technologies. This review also considers the concept of global value chains (GVC) and the points to freeze and thaw seafood along the GVC to improve its quality with the intention of helping Newfoundland and Labrador's emerging Northern cod (Gadus morhua) fisheries enhance product quality, meet market demands and increase stakeholder value. 
1

2 Current freezing and thawing scenarios employed by

3 North Atlantic fisheries: Their potential role on

4 Newfoundland and Labrador's Northern cod (Gadus

5 morhua) fishery

6

7

8

9

10

11

12

13

14

15 Corresponding Author:

16 Deepika Dave ${ }^{1}$

17155 Ridge Road, P.O. Box 4920, St. John's, NL, A1C 5R3, Canada

18 Email address: Deepika.Dave@mi.mun.ca 


\section{Abstract}

22 Seafood is very perishable and can quickly spoil due to three mechanisms: autolysis, microbial 23 degradation, and oxidation. Primary commercial sectors within the North Atlantic fisheries 24 include demersal, pelagic, and shellfish fisheries. The preservation techniques employed across each sector can be relatively consistent; however, some key differences exist across species and regions to maintain product freshness. Freezing has long been employed as a preservation technique to maintain product quality for extended periods. Freezing allows seafood to be held until demand improves and shipped long distances using lower-cost ground transportation while maintaining organoleptic properties and product quality. Thawing is the opposite of freezing and can be applied before additional processing or the final sale point. However, all preservation techniques have limitations, and a properly frozen and thawed fish will still suffer from drip loss. This review summarizes the general introduction of spoilage and seafood spoilage mechanisms and the latest preservation techniques in the seafood industry, focusing on freezing and thawing processes and technologies. This review also considers the concept of global value chains (GVC) and the points to freeze and thaw seafood along the GVC to improve its quality with the intention of helping Newfoundland and Labrador's emerging Northern cod (Gadus morhua) fisheries enhance product quality, meet market demands and increase stakeholder value.

Keywords: Fisheries, Seafood, Freezing, Thawing, Spoilage, Preservation, Global Value Chains, 40 Atlantic cod. 


\section{Introduction}

44 Seafood is highly perishable and very susceptible to spoilage. Ghaly et al. (2010) reported that $30 \%$ of seafood is lost annually due to spoilage. Therefore, food preservation, quality, and storage improvements are essential to increasing value and expanding markets for seafood harvesters and processors. Three primary sectors within the North Atlantic fisheries include demersal, pelagic, and shellfish fisheries. The preservation techniques employed across each fishery can be relatively consistent with slight variations across species and regions.

Spoilage is the result of three mechanisms: autolysis, microbial degradation, and oxidation.

Preservation techniques allow slowing down spoilage mechanisms and help to extend the shelflife of food products (Vaclavik \& Christian 2014). Typical preservation methods commonly used by seafood processors include drying, salting, smoking, pickling, canning, heating, fermenting, chilling, freezing, high-pressure processing (HPP), and modified atmospheric packaging (MAP) (Ghaly et al. 2010; Lauzon et al. 2010; Sigurgisladottir et al. 2000; Vaclavik \& Christian 2014). For centuries, freezing has been employed as a preservation technique to maintain product quality for extended periods (Kaloyereas 1950). Freezing allows seafood to be stored until demand improves, transported long distances at lower costs to markets, and maintain organoleptic properties and quality before secondary processing or final sale. Freezing has been consistently used in commercial applications since Charles Birdseye invented the double belt contact freezer in 1928 (Persson \& Löndahl 1993). Since then, quick-freezing is still the primary process for preserving many seafood products for a few weeks to several months while protecting their original sensory properties (Backi 2018; Hedges 2002; Torry Research Station 1977).

66

Freezing is the subtraction of heat to lower the product's temperature sufficiently that most of the intra- and extracellular water undergoes a phase change from a liquid to a solid (Backi 2015; Haugland 2002; Reid 1993). Freezing techniques employed to slow down autolytic and microbiological degradation and preserve seafood include freezing, frozen storage and thawing (Hanenian \& Mittal 2004). However, holding products in cold storage for extended periods can still lead to the oxidation of lipids and other fats and impact a product's sensory properties and safety aspects (Frankel 1985; Papuc et al. 2017; Secci \& Parisi 2016). Lowering the cold storage temperature, reducing the time held in cold storage, reducing temperature fluctuations, or combining freezing with other preservation methods such as high-pressure processing (HPP), smoking, MAP, and improved packaging materials can help mitigate oxidation and enhance the quality and yield of seafood (Baygar \& Alparslan 2015; Dang et al. 2018b; Dawson et al. 2018; Fuentes et al. 2013; Lauzon et al. 2010; Nakazawa \& Okazaki 2020; Tironi et al. 2010).

Seafood products must be thawed before secondary processing or the final point of sale to highend clients. Thawing is the opposite of freezing; it is the addition of heat to raise the product's temperature and enables the subsequent phase change of the intra- and extracellular water from a 
83 solid to a liquid (Backi 2015; Haugland 2002; Reid 1993). After thawing, the product again has a 84 shortened shelf life and should be processed or sold quickly. A hybrid supply chain where the 85 frozen product undergoes secondary processing and is refrozen, referred to as "twice frozen," is 86 commonly used for Alaskan Pollock (Gadus chalcogrammus) to extend its shelf life (Hedges 87 2002). However, all preservation techniques have their limitations, and a properly frozen and 88 thawed fish can lose $5 \%$ of its weight in drip loss (Dinçer et al. 2009).

89

To the best of our knowledge, this paper is the first of its kind comprehensive review that attempts to: introduce general spoilage and seafood spoilage mechanisms, define preservation techniques employed by the seafood industry to extend shelf-life, and summarize the freezing and thawing processes and technologies used to improve the quality of North Atlantic seafood. It also discusses the Global Value Chains (GVC) for North Atlantic seafood and utilizing freezing and thawing processes along the GVC to improve the quality and value for seafood products; specifically, demersal, pelagic and shellfish species. Moreover, this paper synthesizes applying these technologies to enhance product quality, meet market demands and increase stakeholder value for the re-emerging Northern Cod (Gadus morhua) fishery in Newfoundland and Labrador, Canada. However, the authors have since identified an article with a similar scope (Svendsen et al. 2022).

The intended audience for this review paper includes engineers, researchers, food scientists, and students working in the seafood preservation sector. This paper is also expected to appeal to industry players, specifically food processors looking for guidance to improve product quality and shelf life.

\section{Survey Method}

To ensure an unbiased review of the literature, the authors ran searches using the Memorial University of Newfoundland Library, WorldCat, Web of Knowledge and Google Scholar databases. Keywords used for these searches included: spoilage, preservation, freezing, thawing, seafood and value chain, and keywords were used individually and in combination. Papers identified by each search were initially scanned to determine their appropriateness to the subject, and all relevant articles were read in detail. To increase the breadth of this review, the authors also examined relevant papers referenced by the papers identified during the initial searches.

\section{Definition of spoilage}

118 Spoilage is the deterioration of food material due to biological activities (Biodeterioration 2006),

119 and fish are amongst the most perishable food products. Even with regular refrigerated storage

120 conditions or super-chilling, oxidative, enzymatic, and microbiological spoilage limits fish and

121 fish products' shelf-life (Lauzon et al. 2010; Olafsdóttir et al. 2006; Roiha et al. 2018a).

122 Chemical, microbial, and enzymatic actions are responsible for the biological activities that 
123 cause food spoilage (Ghaly et al. 2010; Lakshmanan 2000; Roiha et al. 2018a). There are three

124 primary causes for spoilage in seafood (Huss et al. 1995; Surette et al. 1988; Tull 1996),

125 including autolytic degradation, bacterial spoilage, and oxidation. Autolytic degradation refers to

126 the self-digestion of the flesh. This degradation includes the natural decay caused by enzymatic

127 changes within the muscle. Bacterial spoilage refers to the contamination of meat by

128 microorganisms. In comparison, oxidation refers to the breakdown of lipids in the flesh due to

129 heat, light, and oxygen. Therefore, proper handling and processing protocols must be employed

130 across the supply chain to minimize spoilage, extend the shelf life of seafood and supply a high-

131 quality product that is safe for consumers (Backi 2018).

132

133 Autolytic spoilage:

134 Huss et al. (1995) define autolytic degradation as self-digestion. Autolysis results from

135 enzymatic changes in the muscle caused by the loss of respiration and homeostasis and digestive

136 enzymes in the gut breaking down the flesh (Backi 2015; Surette et al. 1988). Autolysis is

137 responsible for textural changes to the flesh while in storage (Benjakul \& Bauer 2000; Haugland

138 2002) and reduced freshness (i.e. sensory impairment) with minor microbiological impacts (Huss

139 et al. 1995).

140

141 Glycolysis is the primary enzymatic change occurring in the fish muscle after the death of the

142 animal. The gradual hydrolysis of glycogen into lactic acid instead of carbon dioxide and water

143 due to the lack of oxygen and results in textural changes as the animal goes through rigour-

144 mortis (rigour) (Lakshmanan 2000). Glycolysis can be reduced by minimizing the animal's stress

145 (Ghaly et al. 2010).

146

147 Nucleotide degradation typically follows glycolysis and is responsible for flavour changes in

148 seafood and meat products (Alasalvar et al. 2002; Gram \& Dalgaard 2002; Lakshmanan 2000;

149 Surette et al. 1988). Adenosine diphosphate (ATP) degrades to adenosine monophosphate

150 (AMP) and then to inosine monophosphate (IMP) soon after the animal's death (Alasalvar et al.

151 2002; Surette et al. 1988). Surette et al. (1988) further reported the subsequent production of

152 inosine (INO), hypoxanthine (Hx), xanthine (Xa) and uric acid (URATE) was rate-limited based

153 on the freshness factor (Ki), calculated according to Equation 1 (Karube et al. 1984).

154

$155 K i=\frac{H x+\operatorname{Ino}}{\operatorname{IMP}+\operatorname{Ino}+H x} \times 100$

156

157

158

159

\section{Microbial spoilage:}

160 Food spoilage is a significant concern as the world loses $25 \%$ of the food supply and $30 \%$ of

161 landed fish due to microbial activities (Ghaly et al. 2010). Microbial degradation usually follows

162 autolytic spoilage and further deteriorates the sensory properties (taste, flavour, odour, colour, 
163 texture, and juiciness). Furthermore, microbial degradation of the muscle makes it unsuitable for

164 human consumption (Ghaly et al. 2010; Gram \& Dalgaard 2002). Freshness, the opposite of

165 spoilage, is an essential aspect of food products that require preservation (Cheng et al. 2014).

166

167 Seafood is at its peak freshness immediately after death, and seafood spoilage begins as soon as

168 the animal dies (Huss et al. 1974; Lakshmanan 2000). Therefore, fish harvesters and processors

169 need to understand the effects of spoilage and antemortem and postmortem effects on the muscle

170 (Ashie et al. 1996; Nathanailides et al. 2011; Warrier et al. 1975). The primary specific spoilage

171 bacteria (SSBs) of concern for cold-water marine fish are Pseudomonas spp., Shewanella

172 putrefaciens, Photobacterium phosphoreum, and Proteus spp. (de Alba et al. 2019; Gram \&

173 Dalgaard 2002; Roiha et al. 2018b). As they produce $\mathrm{H}_{2} \mathrm{~S}$ under aerobic conditions, these

174 bacteria break down the animal's flesh by secreting enzymes as they multiply (Castell 1954;

175 Gram \& Huss 1996) and lead to microbial and enzymatic spoilage.

176

177 Under suitable environmental conditions, seafood becomes a source of nutrients that can support

178 the growth of a wide range of bacteria (Castell \& Anderson 1948; Gram \& Dalgaard 2002;

179 Lakshmanan 2000; Seremeti 2007). Furthermore, these bacteria remain active under

180 temperatures below $0^{\circ} \mathrm{C}$; however, their activity is reduced with every degree drop in

181 temperature (Castell 1954; Ghaly et al. 2010; Huss et al. 1995). Table 1 presents the decrease in

182 fish products' expected shelf life with increasing temperature (Huss et al. 1995).

183

184 Oxidation spoilage:

185 As seafood is held in cold storage, composition changes result in lipid and protein oxidation, 186 protein degradation, and the loss of other vital molecules (Ghaly et al. 2010; Papuc et al. 2017).

187 Oxidation spoilage is the reaction between oxygen and unsaturated lipids. It produces a wide

188 range of unwanted compounds responsible for rancidity, undesirable flavours and odours, and

189 potential toxicity of the flesh (Badii \& Howell 2002; Frankel 1985; Papuc et al. 2017; Secci \&

190 Parisi 2016). Lipid oxidation typically occurs when a product is held for too long in cold storage

191

192

193 The three stages of lipid oxidation are initiation, propagation, and termination (Ghaly et al. 2010;

194 Kolanowski et al. 2007). During the initiation phase, lipid-free radicals are formed by adding

195 heat and oxygen to form peroxyl radicals. During the propagation phase, hydroperoxides are

196 created when the peroxyl radicals react with other lipids. Finally, secondary oxidation products

197 such as hydrocarbons, aldehydes and ketones are formed during the termination phase, and

198 unsaturated aldehydes and ketones are oxidized further to produce volatile compounds. These

199 changes result in off-flavours and signal that the product is no longer edible (Ghaly et al. 2010;

200 Kolanowski et al. 2007; Lorentzen et al. 2019).

201 
202 Oxidation typically occurs when the product is held for too long in cold storage or at high 203 temperatures (Castell 1954; Dawson et al. 2018; Indergård et al. 2014). Oxidation usually affects

204 frozen seafood and results in a typical cold storage flavour, off-colours and protein breakdown

205 (Badii \& Howell 2002; Bøknæs et al. 2000). Off-flavours typically increase with time and

206 temperature during frozen storage and result from the formation of hept-cis-4-enal,

207 hept-trans-2-enal and hept-trans-2, cis-4-dienal (McGill et al. 1974; McGill et al. 1977). Badii \&

208 Howell (2002) reported that oxidation of lean flesh such as cod resulted in texture changes.

209 Nakazawa \& Okazaki (2020) and Tolstorebrov et al. (2016) reported that rapid freezing and cold

210 storage at $-30^{\circ} \mathrm{C}$ helped minimize protein denaturation. Therefore, optimizing the freeze time and

211 temperature of frozen storage for seafood is essential for maintaining quality, especially for fish

212 with higher lipid content.

213

214 Cod Spoilage:

215 Understanding the mechanisms that cause spoilage in cod is essential for implementing

216 preservation techniques and optimizing value. In cod, autolytic degradation occurs first, followed

217 by microbiological spoilage. Ghaly et al. (2010), Gram \& Dalgaard (2002) and Huss et al. (1995)

218 discussed the significant contribution of microbial growth and autolytic degradation responsible

219 for fish spoilage. Therefore, it is essential to minimize spoilage while optimizing the value of the

220 resources. Table 2 summarizes the four phases of eating quality for cod stored on ice (Huss et al.

221 1995).

222

223

224

225

226

227

228

229

230

231

232

233

234

235

236

237

238

\section{Seafood Preservation Techniques}

Slowing down spoilage mechanisms is the objective of food preservation techniques (Vaclavik \& Christian 2014). Kaloyereas (1950) provided a detailed history of food preservation techniques and their adoption by early civilizations who learned the benefits of preserving foodstuffs, likely by accident, and discussed the impacts science has had on the progression of preservation methods. Conventional preservation techniques used in industry include salting, drying, smoking, pickling, canning, heating, fermenting, chilling, and freezing (Ghaly et al. 2010; Lauzon et al. 2010; Vaclavik \& Christian 2014). However, many of these techniques may change the product's organoleptic properties, such as taste, flavour, odour, texture, and juiciness. The following sections of this review paper will focus on freezing and thawing as preservation methods; if employed correctly, allow products to retain their fresh taste and texture (Kolbe \& Kramer 2007).

\section{Freezing and freezing techniques}

Retaining the quality of fish is the primary focus of preservation techniques such as freezing.

239 Freezing is the most common preservation method for many seafood products and has been used for thousands of years to help maintain high product quality (Alizadeh et al. 2007; Gonçalves et al. 2012). Freezing, as a preservative, typically includes three operations: freezing, frozen storage and thawing (Hanenian \& Mittal 2004). Freezing fish lowers the product's temperature and slows 
242 down spoilage, so when the product is thawed, it is virtually identical to fresh fish (Torry

243 Research Station 1977). However, the ice crystals formed during the process can severely

244 damage the product, so the freezing kinetics should be designed to optimize the ice crystals' size,

245 shape, and distribution (Otero et al. 2016).

246

247 Freezing entails two linked processes: lowering the temperature sufficiently to remove the

248 sensible and latent heat from a product and subsequent phase change of the intra- and

249 extracellular water from a liquid to solid (Backi 2015; Haugland 2002; Reid 1993; Singh \&

250 Heldman 2009). Freezing consists of four phases, precooling, nucleation, phase transition and

251 tempering (Otero et al. 2016). Equation 2 describes the thermodynamic relationship for freezing

252 (Backi 2018).

253

$254 d h=c(T)\left(T_{i}-T_{f}\right)+L_{f}$

255

256

Where: $\quad d h=$ the heat energy removed from the fish

257

258

259

260

261

262

263

264

265

266

267

268

269

270

271

$\mathrm{c}(\mathrm{T})=$ the specific heat capacity (temperature dependent)

$\mathrm{Ti}=$ the initial temperature of the fish

$\mathrm{Tf}=$ the final, or desired, temperature of the fish

$\mathrm{Lf}=$ the latent heat of fusion

In this case, the latent heat of fusion is the amount of energy that must be subtracted to undergo the phase change (Vaclavik \& Christian 2014).

Freezing minimizes water activity and slows down the deterioration caused by enzymes and microorganisms by reducing the product's temperature below their active range (Connell 1980; Svendsen et al. 2022)) and its use as a preservative was first attributed to the Chinese around 100 BC (Kaloyereas 1950). More recently, William Cullen, Jacob Perkins, Ferdinand Carré, Carl von Linde, and Clarence Birdseye developed and improved the freezing technology currently used in many modern seafood processing plants (Appel 1990; Kaloyereas 1950; Persson \& Löndahl 1993).

272

273

Freezing also enables processors to optimize processing, transporting, marketing, and retailing

274 requirements by extending product freshness and quality for a few weeks to several months

275 (Backi 2018; Fuentes et al. 2013). Cold storage may also permit the use of slower, less carbon-

276 intensive transportation methods to ship products to lower-cost secondary processors or markets

277 (Ziegler et al. 2013).

278

279

However, freezing techniques have limitations. A typical, properly frozen and thawed fish can

280 lose $5 \%$ of its weight through drip loss (Dinçer et al. 2009). Once frozen, seafood must be held in 281 cold storage at $-18^{\circ} \mathrm{C}$ or below to preserve its freshness (FAO \& WHO 2020). However, 
282 Nakazawa \& Okazaki (2020) reported that even at the temperatures that most commercial 283 ethylene-glycol freezers are designed to operate at $\left(-20^{\circ} \mathrm{C}\right.$ to $\left.-25^{\circ} \mathrm{C}\right)$, protein denaturation for 284 many cold-water species may still occur due to the presence of psychrophiles. Therefore, colder

285

286

287

288

289

290

291

292

293

294

295

296

297

298

299

300

301

302

303

304

305

306

307

308

309

310

311

312

313

314

315

316

317

318

319

320

321 storage temperatures of $-30^{\circ} \mathrm{C}$ to $-40^{\circ} \mathrm{C}$ are recommended to maintain quality. Furthermore, if this cold chain is not maintained, thawing and subsequent refreezing will result in ice crystal formation and damage the flesh (Dawson et al. 2018; Fuentes et al. 2013; Gonçalves et al. 2012; Washburn et al. 2017). This thermal abuse results in additional drip loss and will further degrade the organoleptic and sensory properties such as taste, flavour, odour, colour, texture, and juiciness of the fish (Garthwaite 1997; Karthikeyan et al. 2015; Rehbein 2002). It is also crucial for the processors to replace their stock on a first-in, first-out basis to help prevent oxidative spoilage by minimizing the cold storage time. This spoilage is significant when species contain high lipid content (Ghaly et al. 2010; Kolanowski et al. 2007; Lorentzen et al. 2019).

Studies have shown that slower freezing rates typically result in the formation of larger ice crystals and severe damage to the cellular structure, osmotic water loss, denaturation of protein and mechanical damage to the fillet (Alizadeh et al. 2007; Benjakul \& Bauer 2000; Chevalier et al. 2000). Small amounts of cellular damage are hardly noticeable as the product will reabsorb the lost water during the thawing process. However, Nakazawa \& Okazaki (2020) reported that improper freezing and cold storage would result in significant protein denaturation and cellular damage such as gaps and drip loss. Rapid freezing freezes the product more quickly, reduces ice crystal size, minimizes damage to the flesh, captures the product's quality and freshness and holds it until the product is thawed (Backi 2018; Benjakul \& Visessanguan 2010; Chevalier et al. 2000; Otero et al. 2016; Rehbein 2002). Rapid freezing techniques employed by seafood processors worldwide include blast freezing, plate freezing, impingement tunnel freezing, immersion freezing, and cryogenic freezing.

Commercial freezers typically fall into two categories, (a) indirect and (b) direct contact (Fig. 1) Direct contact systems (i.e., air blast and immersion freezers) put the product in direct contact with the freezing medium. In contrast, indirect systems (i.e. plate freezers) operate by placing a barrier between the product and cooling medium (Singh \& Heldman 2009). Both direct and indirect contact systems can apply to batch (where the product remains stationary) or continuous (where the product is conveyed through the freezer) configurations(Fig. 2) (Seremeti 2007). Newfoundland and Labrador seafood processors employ these commercial freezing systems (slowest to fastest): still, blast, plate, impingement tunnel, and immersion freezing. Higher speed processes, such as cryogenic freezing, are less common in Newfoundland and Labrador, Canada, due to the lack of availability and cost of the gasses required to operate them. Several novel freezing methods that have not found commercial success include ultralow temperature freezing, ultrarapid freezing, dehydrofreezing, ultrahigh pressure and ultrasound (Li \& Sun 2002; Wu et al. 2017). Once frozen, fish are held in cold storage at $-18^{\circ} \mathrm{C}$ or lower, awaiting further distribution (FAO \& WHO 2020). 
322

323

324

325

326

327

328

329

330

331

332

333

334

335

336

337

338

339

340

341

342

343

344

345

346

347

348

349

350

351

352

353

354

355

356

357

358

359

360

\section{Still freezing:}

Walk-in and other still air freezers (Fig. 3a) function by holding the product in an insulated, cold air chamber at -5 to $-30^{\circ} \mathrm{C}$ until the product freezes using natural circulation and limited circulation from evaporator fans (Dempsey \& Bansal 2012; Kolbe \& Kramer 2007). The heat transfer mechanism is convection using air as the cooling medium (Laguerre \& Flick 2004). Air is a poor conductor of heat, so cooling rates tend to be slower in still air freezers; consequently results in the formation of larger, primarily extracellular ice crystals, more significant cellular damage and greater drip loss (Dempsey \& Bansal 2012; Jessen et al. 2014; Kolbe \& Kramer 2007; Singh \& Heldman 2009; Suh et al. 2017). Kolbe \& Kramer (2007) reported a typical heat transfer coefficient $\mathrm{U}=5.7 \mathrm{~W} \cdot \mathrm{m}^{-2} \cdot \mathrm{K}^{-1}$, and Fellows (2016) reported a freezing rate of $2 \mathrm{~mm} \cdot \mathrm{h}^{-1}$ for still air freezers. On the positive side, still freezers are relatively inexpensive to purchase and operate; therefore, typically used in commercial applications for cold storage or transportation of frozen products (Boonsumrej et al. 2007; Jessen et al. 2014; Norsworthy 2015).

\section{Blast freezing:}

Air-blast freezers (Fig. 3b) are commonly used in commercial settings, especially land-based plants, to freeze seafood (Backi 2018; Dempsey \& Bansal 2012; Jessen et al. 2014). Blast freezers are considered quick freezers and can reduce the product's temperature through the critical zone $\left(0^{\circ} \mathrm{C}\right.$ to $\left.-5^{\circ} \mathrm{C}\right)$ in less than 5 to $10 \mathrm{~h}$ (Fellows 2016; Jessen et al. 2014; Suh et al. 2017). Typical refrigerant temperatures range between $-35^{\circ} \mathrm{C}$ to $-52^{\circ} \mathrm{C}$ and air temperatures between $-26^{\circ} \mathrm{C}$ to $-40^{\circ} \mathrm{C}$ (Alizadeh et al. 2007; Boonsumrej et al. 2007; Cheng et al. 2014; Dempsey \& Bansal 2012). Garthwaite (1997) reported that air speeds around $5 \mathrm{~m} \cdot \mathrm{s}^{-1}$ are economical for batch processes; however, $10-15 \mathrm{~m} \cdot \mathrm{s}^{-1}$ are recommended air speeds for continuous processes to lower the contact time with the freezing media. Fellows (2016) and Johnston et al. (1994) reported blast freezing rates of 2 to $5 \mathrm{~mm} \cdot \mathrm{h}^{-1}$. Kolbe \& Kramer (2007) stated a typical heat transfer coefficient $\mathrm{U}=22.7 \mathrm{~W} \cdot \mathrm{m}^{-2} \cdot \mathrm{K}^{-1}$, confirming the relative increase in cooling rate of forced convection vs. natural convection.

Tunnel (Fig. 3c) and spiral freezers (Fig. 3h) are examples of continuous blast freezers. These freezers operate the same as batch-style blast freezers, except there is a constant product transfer through the chamber and direct application of cold air on the foodstuff (Backi 2015). This direct cooling produces a higher typical heat transfer coefficient $\mathrm{U}=56.8 \mathrm{~W} \cdot \mathrm{m}^{-2} \cdot \mathrm{K}^{-1}$ and faster relative freezing rates up to $30 \mathrm{~mm} \cdot \mathrm{h}^{-1}$ (Fellows 2016; Johnston et al. 1994; Kolbe \& Kramer 2007). Airimpingement freezers are examples of a straight-belt freezer where the product is cooled from the top and bottom with high-velocity cold air. These systems cost less than cryogenic freezers and have heat transfer coefficients approaching $350 \mathrm{~W} \cdot \mathrm{m}^{-2} \cdot \mathrm{K}^{-1}($ Dempsey \& Bansal 2012; Fellows 2016). 
361 In contrast, air blast freezers need regular downtime for defrosting, especially with continuous 362 processes (Garthwaite 1997). They are also more expensive to operate because their large fans

363 require considerable electricity to operate and cause a significant impact on the cooling system's

364 total heat load (Dempsey \& Bansal 2012). Moreover, there is a potential for dehydration leading

365 to lipid oxidation and freezer burn in unwrapped and unglazed products, especially at higher

366 airflow rates (Dempsey \& Bansal 2012; Jessen et al. 2014; Seremeti 2007).

367

368

\section{Plate freezing:}

369 The plate freezer is another quick freezing technology commonly employed by seafood

370

371

372

373

374

375

376

377

378

379

380

381

382

383

384

385

386

387

388

389

390

391

392

393

394

395

396

397

398

399

400

processors (Backi 2015; Johnston et al. 1994). The plates are fabricated from aluminum

extrusions which allow refrigerant between -30 to $-50^{\circ} \mathrm{C}$ to be pumped through the interior while the product is held between two refrigerated plates for a sufficient duration to enable freezing (Backi 2015; Fellows 2016; Hedges 2002; Johnston et al. 1994; Kolbe \& Kramer 2007; Torry Research Station 1977). Plate freezers employ conduction, so cooling times are typically much quicker than air blast freezers (Backi 2015; Dempsey \& Bansal 2012; Vaclavik \& Christian 2014). Plate freezers employ a higher typical heat transfer coefficient $\mathrm{U}=56.8$ to $600 \mathrm{~W} \cdot \mathrm{m}^{-2} \cdot \mathrm{K}^{-1}$ and faster relative freezing rates up to $30 \mathrm{~mm} \cdot \mathrm{h}^{-1}$ (Fellows 2016; Johnston et al. 1994; Kolbe \& Kramer 2007).

Plate freezers are predominantly constructed in two formats, vertical (Fig. 3g) and horizontal (Fig. 3d), based on the orientation of the contact plates (Backi 2015; Johnston et al. 1994; Seremeti 2007; Vaclavik \& Christian 2014). Horizontal plate freezers work best for freezing fillets, surimi, mince, and packaged products with large flat surfaces, while vertical plate freezers are typically used for freezing whole fish into blocks both at sea and onshore (Backi 2015; Kolbe \& Kramer 2007; Torry Research Station 1977). The merits of plate freezers include faster cooling, a relatively small footprint, low operating costs, and minimal product dehydration (Fellows 2016; Johnston et al. 1994). The primary detriment against plate freezers is their lack of versatility and the need for deformable and uniformly shaped products (Seremeti 2007). Other detractions include batch operation, ice buildup potential on the plates, and products adhering to the plates during freezing (Kolbe \& Kramer 2007; Seremeti 2007; Torry Research Station 1977).

\section{Immersion freezing:}

Immersion freezers (Fig. 3f) are an example of a direct contact freezer. They are classed as rapid freezers with freezing rates of 50 to $100 \mathrm{~mm} \cdot \mathrm{h}^{-1}$ and higher typical heat transfer coefficient $\mathrm{U}=$ 210 to $290 \mathrm{~W} \cdot \mathrm{m}^{-2} \cdot \mathrm{K}^{-1} ; 680$ to $740 \mathrm{~W} \cdot \mathrm{m}^{-2} \cdot \mathrm{K}^{-1}$ using forced convection (Fellows 2016 ; Seremeti 2007; Singh \& Heldman 2009). Immersion freezers operate by chilling a brine solution between -20 to $-55^{\circ} \mathrm{C}$ and immersing the product into it (Fellows 2016; Johnston et al. 1994; Singh \& Heldman 2009). Paddles or a conveyor move the product from the entry to the exit end where the product is packaged. Seafood, e.g., tuna, shrimp, lobster and crab, that require rapid cooling are immersed directly in a salt brine (Kolbe \& Kramer 2007; Seremeti 2007). CODEX standards 
401 recommend that salt pick-up, or penetration into the flesh, be kept to a minimum to avoid 402 negatively affecting the product's taste (FAO \& WHO 1980; Seremeti 2007). Almy \& Field 403 (1921) reported that an average salt penetration of $2.88 \%$ on a dry weight basis was acceptable, 404 consistent with the 3 to $4 \%$ reported by Graiver et al. (2009) for pork. Other products are packaged first before being immersed in refrigerant (Fellows 2016). The merits of immersion 406 freezing include high-speed freezing, efficiency and, low capital and operating costs (Fellows 2016; Kolbe \& Kramer 2007; Singh \& Heldman 2009). The demerits include the requirement of larger pumps to counter the viscosity of low temperature brines, the potential for corrosion, the possibility of introducing off-flavours in the unpackaged product, and the toxicity of some brines (Backi 2015; Johnston et al. 1994; Kolbe \& Kramer 2007; Seremeti 2007).

412 Cryogenic freezing:

413 Cryogenic freezers (Fig. 3e) are a type of ultrarapid freezers. They typically refer to any system 414 where the refrigerant is sprayed directly into the freezing cabinet, comes directly in contact with 415 the product, vaporizes and is discharged into the atmosphere (Fellows 2016; Jessen et al. 2014; 416 Kolbe \& Kramer 2007). Their refrigerants are typically liquid carbon dioxide with a boiling 417 point of $-78.5^{\circ} \mathrm{C}$ or liquid nitrogen with a boiling point of $-196^{\circ} \mathrm{C}$ with average temperatures within the cabinet between -50 to $-100^{\circ} \mathrm{C}$ (Backi 2015; Boonsumrej et al. 2007; Jessen et al. 2014). The merits of cryogenic freezers include their relatively small size, continuous operation, ability to accept nonuniform product size or shape, low capital cost, very high heat transfer coefficients approaching $\mathrm{U}=1500 \mathrm{~W} \cdot \mathrm{m}^{-2} \cdot \mathrm{K}^{-1}$, and ultrarapid freezing rates of 100 to $1000 \mathrm{~mm} \cdot \mathrm{h}-$ 1 (Fellows 2016; Jessen et al. 2014; Johnston et al. 1994; Kolbe \& Kramer 2007). Espinoza Rodezno et al. (2013) and Boonsumrej et al. (2007) reported lower lipid oxidation and drip loss of cryogenically frozen products after thawing. The demerits of cryogenic freezers include their high operating cost, scarcity of liquified gasses, risk of freeze-cracking, and greenhouse effects if $\mathrm{CO}_{2}$ is used as the refrigerant (Backi 2015; Kolbe \& Kramer 2007; Seremeti 2007). A relative comparison of these freezing methods is summarized in Table 3.

428

\section{Thawing and thawing techniques}

430 Improved thawing methods are essential for fish processing due to the growing use of freezing as a preservation method by processors (Indzere et al. 2020; Jason 1974). However, Haugland

432 (2002) reported that while $75 \%$ of Norwegian processors used thawing in their production, $93 \%$ 433 of these processors relied upon uncontrolled thawing methods. This uncontrolled thawing can 434 provide a favourable temperature for microbes to return into active form and spoil the product 435 (Indzere et al. 2020). Primarily, these processors batch thawed fish using either running water or 436 air. Furthermore, there is less published research regarding commercial thawing than freezing; a 437 Web of Science database search (https://apps.webofknowledge.com) yielded 1355 articles from 438 2017-2021 for "fish" AND "freezing" but only 374 articles for "fish" AND "thawing" over the 439 same timeframe (Fig. 4). 
441 Thawing is the opposite process of freezing; the addition of heat to raise a product's temperature 442 to enable the subsequent phase change from a solid to liquid (Haugland 2002; Reid 1993). In 443 this case, the latent heat of fusion is the amount of energy added to undergo the phase change 444 (Vaclavik \& Christian 2014). Therefore, Equation 1 is equally valid for thawing; however, the 445 heat capacity is $4.18 \mathrm{~kJ} \cdot \mathrm{kg}^{-1} \cdot \mathrm{K}^{-1}$ for liquid water and $2.04 \mathrm{~kJ} \cdot \mathrm{kg}^{-1} \cdot \mathrm{K}^{-1}$ for ice. Backi (2018) also 446 observed that freezing is faster than thawing because ice is a better conductor of heat than liquid

447

448

449

450

451

452

453

454

455

456

457

458

459

460

461

462

463

464

465

466

467

468

469

470

471

472

473

474

475

476

477

478

479

480 water. Reid (1993) reported that it takes three to four times longer to thaw a product from $-80^{\circ} \mathrm{C}$ to $+80^{\circ} \mathrm{C}$ than the inverse, and Fellows (2016) further noted that the insulating effect of the water increased with thawing, further slowing the process down. Jason (1974) reported an upper temperature bound to thawing, notably that thawing above $20^{\circ} \mathrm{C}$ resulted in quality challenges and thawing above $30^{\circ} \mathrm{C}$ resulted in cooking; therefore, thawing must be controlled to minimize any unwanted effects such as dehydration or overheating of the flesh.

Haugland (2002) reported that the principles of heat transfer could also be applied to thawing. Heat transfer through the surface by convection or conduction and heat generation within the product using microwaves, ultrasound, dielectric methods, and electric resistance. Conventional thawing techniques employed by seafood processors include still air thawing, forced convection thawing, water sprinkling and water immersion thawing (Ragnarsson \& Viðarsson 2017). These methods use heat transfer through the surface and are inefficient, slow and inconvenient (Cai et al. 2019). Unconventional thawing methods include vacuum, humidified forced convection, high-pressure, microwave, ohmic, high voltage electrostatic field, ultrasound, and radiofrequency thawing (Cai et al. 2019; Cai et al. 2020; Coolnova n.d.; Li \& Sun 2002; Min et al. 2016; Mousakhani-Ganjeh et al. 2015; Ragnarsson \& Viðarsson 2017; Roiha et al. 2018b; Wu et al. 2017). Regardless of the thawing process selected, processors should be wary of: bacterial growth, excess drip loss, dehydration, and localized overheating of the product (Garthwaite 1999). Once thawed, fish are kept on ice or held in refrigerated storage until they are sold or undergo secondary or value-added processing.

\section{Thawing in still air:}

Thawing in still air (Fig. 5a) employs natural convection and conduction to thaw (Backi 2015; Haugland 2002; Jason 1974) and is the simplest and cheapest method commonly used by fish processors (Garthwaite 1999; Klinkhardt 2013; Ragnarsson \& Viðarsson 2017). Air thawing involves either storing the frozen product in ambient temperatures overnight or in chilled temperatures $\left(<4^{\circ} \mathrm{C}\right)$ for a prolonged period to facilitate slow thawing (Archer et al. 2008). Jason (1974) reported that thawing in still air is a slow process capable of thawing rates approaching 10 $\mathrm{mm} \cdot \mathrm{h}^{-1}$ at $15^{\circ} \mathrm{C}$ for whole cod. Thawing can be sped up by placing the product on grated racks to improve air circulation around the product (Archer et al. 2008).

Thawing in still air is typically executed as a batch process that requires a significant amount of time, labour and space (Garthwaite 1999; Ragnarsson \& Viðarsson 2017). When air thawing, 
481 temperatures should be kept below $20^{\circ} \mathrm{C}$ to minimize bacterial growth; however, temperatures 482 should not be kept too low as extended thawing periods can also lead to bacterial growth, lipid 483 oxidation, reduced yield, and spoilage (Backi 2015; Garthwaite 1999; Gonçalves et al. 2012; 484 Regenstein \& Regenstein 1991). Lastly, when thawing in still air, a boundary layer of cold air 485 forms around the fish, slowing thawing down and reducing control of the process (Haugland 486 2002; Ragnarsson \& Viðarsson 2017).

487

488

489

490

491

492

493

494

495

496

497

498

499

500

501

502

503

504

505

506

507

508

509

510

511

512

513

514

515

516

517

518

Air blast thawing:

Forced convection will help prevent the boundary layer from forming and speed up thawing (Backi 2015; Haugland 2002; Jason 1974; Regenstein \& Regenstein 1991). Garthwaite (1999) recommends air speeds of 8-10 m.s $\mathrm{s}^{-1}$ for optimal heat transfer. Supplementing forced convection with heat will improve thawing rates further; Figure $5 \mathrm{~b}$ depicts the product on pallets with warm air blown over the product by circulation fans. This method is still relatively inexpensive and can improve thaw rates.

Some detractions to air blast thawing include additional capital and operating costs of the fans, increased maintenance costs and potential downtime, and the potential for hotspots and uneven air distribution (Archer et al. 2008). Like thawing in still air, batch processing, significant space requirements, the potential for lipid oxidation, product drying near the surface, and growth of microorganisms at higher temperatures still exist (Backi 2015; Regenstein \& Regenstein 1991).

\section{Thawing in humidified air:}

Some of the challenges associated with thawing in air, specifically lipid oxidation and dehydration, can be mitigated by humidifying the air (Backi 2015; Jason 1974). Furthermore, Jason (1974) reported that thawing in $20^{\circ} \mathrm{C}$ humidified air moving at $8 \mathrm{~m} \cdot \mathrm{s}^{-1}$ can produce thawing rates approaching $25 \mathrm{~mm} \cdot \mathrm{h}^{-1}$. Indzere et al. (2020) stated that thawing in forced, humidified air was the most efficient thawing method. The Coolnova ${ }^{\circledR}$ chamber (Fig. $5 \mathrm{c}$ ), which has found some commercial success in Europe (Coolnova n.d.), is an example of a humidified air thawing system. Product thaws rapidly in a humidified air system at a temperature of 20 to $30^{\circ} \mathrm{C}$ and relative humidity of 85 to $100 \%$ due to the humid, convective, warm air. Vendors claim this method maintains the fresh quality, taste, smell and appearance of foods with minimal drip loss (Coolnova n.d.). Furthermore, these systems are available as batch systems for smaller users; and continuous systems for larger processors.

Detractions of thawing in humidified air include higher start-up and operating costs, the potential for overheating the product's surface, the need for regular maintenance and cleaning, inconsistent programming times required due to product size and shape, and higher energy costs

519

520 (Archer et al. 2008; Ragnarsson \& Viðarsson 2017).

\section{Immersion in water thawing:}


521 Another widely used thawing method is water immersion (Backi 2015; Jason 1974; Regenstein

$522 \&$ Regenstein 1991). Immersion thawing can be a simple batch process (Fig. 5d); placing the

523 product in 300-1000 litre totes of running water and left to thaw to a computer-controlled, self-

524 unloading, automated process (Fig. 5e). Backi (2018) reported thawing rates of $25-34 \mathrm{~mm} \cdot \mathrm{h}^{-1}$ at a

525 constant temperature of $15.5^{\circ} \mathrm{C}$. Immersion thawing should incorporate a recirculation system,

526 such as aeration, to conserve heat and water (Fig. 5f). To thaw the product in aerated water, place

527 the frozen fillets in a tub of water and bubble air into the tub to circulate the water using a

528 manifold placed in the tank connected to an air compressor. Lipid oxidation and surface drying

529 were minimized or eliminated using this thawing technique (Backi 2018).

530

531 The potential challenges with thawing in water include absorption of water and subsequent loss

532 of flavour (Gonçalves et al. 2012; Jason 1974), product contamination (Jason 1974; Regenstein

$533 \&$ Regenstein 1991), potential yield loss in partially thawed product, and water usage, treatment,

534 and disposal costs (Archer et al. 2008).

535

536 Ultrahigh-pressure thawing:

537 There has been significant research on applying ultrahigh-pressure thawing techniques to

538 foodstuffs (Cui et al. 2019; de Alba et al. 2019; Rouillé et al. 2002; Rubio-Celorio et al. 2015;

539 Wen et al. 2015; Wu et al. 2017). The effects of ultrahigh-pressure thawing are typically

540 associated with temperature, pressure, and pressure change rate (Backi 2015; Cai et al. 2019;

541 Chevalier et al. 1999; Wu et al. 2017). At higher pressure (Fig. 6), the freezing point of liquid

542 water drops from $0^{\circ} \mathrm{C}$ atmospheric pressure to $-21^{\circ} \mathrm{C}$ at $210 \mathrm{MPa}$ (Backi 2018; Wu et al. 2017).

543 Chevalier et al. (1999) reported that the effective thawing time for fillets in a $10^{\circ} \mathrm{C}$ water bath

544 decreased four-fold between atmospheric pressure and $200 \mathrm{MPa}$; Rouillé et al. (2002) obtained

545 optimal thawing results at a pressure of $150 \mathrm{MPa}$. Ultrahigh-pressure systems used in the food

546 processing industry (Fig. $5 \mathrm{~g}$ ) tend to be high-precision, mechanized devices that use hydraulic

547 intensifiers to increase pressure and require significant maintenance (Archer et al. 2008; Backi

548 2018). The merits of ultrahigh-pressure thawing include improved water holding capacities and

549 less drip loss during the thawing process (Ragnarsson \& Viðarsson 2017; Rouillé et al. 2002; Wu

550 et al. 2017).

551

552 Ultrahigh-pressure thawing is a novel technology with limited practicality due to its high costs

553 (Indzere et al. 2020). Archer et al. (2008) also reported that tuna fillets thawed using ultrahigh-

554 pressure resulted in unfavourable colour changes.

555

556 A relative comparison of the thawing methods presented above is summarized in Table 4.

557

558 To choose the correct preservation treatment, processors need to understand the market and

559 consumers' expectations. For example, freezing is the primary preservation method

560 Newfoundland and Labrador's cod processors use to bridge the gap between the timing and 
561 location of their fisheries and the clients' needs for a thawed product that compares closely to

562 fresh. However, freezing techniques have their limitations as degradation of organoleptic and

563 sensory qualities such as taste, texture, and juiciness if the freezing and thawing methods are not

564 optimized. The correct application of freezing throughout the cold chain combined with an

565 optimized thawing process is needed to maximize quality and increase value.

566

567

568

569

570

571

572

573

574

575

576

577

578

579

580

581

582

583

584

585

586

587

588

589

590

591

592

593

594

595

596

597

598

599

600

\section{Effect of Freezing and Thawing on the Quality of Seafood}

Freezing is an efficient method to maintain seafood quality and maintain the product's fresh taste (Dang et al. 2018a). However, as already reported, some deterioration can still occur during freezing. Therefore, seafood quality and storage life depend on several variables, including species, initial product quality, initial microbial load, handling, freezing rate, storage temperature, packaging, thawing method and cold chain abuse (Baygar \& Alparslan 2015; Dang et al. 2018a; Dawson et al. 2018; Fuentes et al. 2013). Improper freezing and thawing techniques can result in quality defects, including poor colour and texture and freezer burn (Chevalier et al. 2000; Frelka et al. 2019). Slow freezing of cod results in larger ice crystal size, creating network structures in the flesh and resulting in a spongy texture after thawing (Nakazawa \& Okazaki 2020). Improper long-term cold storage can result in protein denaturation, lipid oxidation and rancidity (Ghaly et al. 2010; Kolanowski et al. 2007; Lorentzen et al. 2019; Nakazawa \& Okazaki 2020). Cold-chain abuse and sublimation can result in the thawing and recrystallization of ice, resulting in larger, more irregular crystals. These ice crystals can increase damage to the muscle structure and reduce product quality by decreasing water holding capacity and juiciness (Dawson et al. 2018; Tironi et al. 2010); the loss of bound water is referred to as drip loss.

Global value chains (GVC) within the seafood industry have been discussed in detail (Jensen \& Sørensen 2016; Knútsson et al. 2016; Norsworthy 2015; Phyne et al. 2006; PrimeFish 2017; Trondsen 2012; Witter \& Stoll 2017). The GVC for seafood is defined as the activities needed to bring a product from capture or harvest to the final consumer. These activities may vary based on species, finished product, region, and vertical integration within the sector (Kaplinsky 2004; PrimeFish 2017). Witter \& Stoll (2017) presented a typical GVC for seafood (Fig. 7), which identifies potential GVC activities, and each of these interactions can potentially impact the quality of the final product (Secci \& Parisi 2016). The primary steps identified in typical GVC cold chains include post-processing, distribution, marketing, secondary processing, and final distribution; not all activities in the GVC apply to all fisheries.

Outsourcing significant value-added processing to lower-cost countries such as China, Vietnam, and Lithuania helps minimize costs (PrimeFish 2017; Stringer et al. 2011; Verge 2017) and is partially responsible for additional freezing and thawing. Therefore, for this paper, North Atlantic commercial fisheries will refer to wild-caught or farmed species prosecuted in North Atlantic waters by European, Canadian and United States interests with a minimum acceptable amount of domestic or onboard processing. The main commercial sectors for the North Atlantic 
601 fisheries include demersal, pelagic, and shellfish species (DFO 2018a; National Marine Fisheries

602 Service 2017; PrimeFish 2017). This study will disregard other sectors such as roe, marine

603 mammals, and marine plants due to their relative sizes or the lack of available information.

604

605 Demersal species

606 Demersal species refer to fish that dwell or feed on or near the seabed (Bender 2014a). These

607 species, commonly referred to as groundfish or whitefish, fall into two categories: round (i.e.,

608 cod or halibut) or flat (i.e., flounder or turbot). Bayliss (1996) reported that the flesh of demersal

609 fish is translucent grey-white due to low myoglobin content and that it only contains up to $2 \%$ fat

610 because demersal fish store the oil in their livers. Several key, commercial, North Atlantic

611 groundfish species include Atlantic cod (Gadus morhua), Ocean perch (Sebastes marinus),

612 Golden redfish (Sebastes norvegicus), Silver hake (Merluccius bilinearis), Atlantic halibut

613 (Hippoglossus hippoglossus), Haddock (Melanogrammus aeglefinus), Summer flounder

614 (Paralichthys dentatus), and Saithe (Pollachius virens) (DFO 2018a; ICES 2019; National

615 Marine Fisheries Service 2017; Norsworthy 2015). Commercially, groundfish is caught using

616 longlines, trawls, pots/traps, seines and gill nets (Jennings et al. 2001; Montgomerie 2015).

617 Seasonality and gear choice can affect quality; however, these topics fall outside the scope of this

618 review paper.

619

620 Key groundfish species caught in North Atlantic fisheries include cod, halibut, haddock,

621 flounder, and turbot. Each of these species supports commercial fishing in Europe and North

622 America (DFO 2018a; National Marine Fisheries Service 2017; PrimeFish 2017), with a mixture

623 of fresh and frozen landings (ICES 2019; National Marine Fisheries Service 2017; PrimeFish

624 2017). The GVC for groundfish fisheries can vary by species, region, season, capture method

625 and degree of processing; however, they typically adhere to the model presented in Figure 7

626 (Knútsson et al. 2016; Witter \& Stoll 2017).

627

628

After harvest, removing the gut material and cleaning the internal cavity is typically carried out

629 to minimize autolytic and microbiological degradation (Ghaly et al. 2010; Hanenian \& Mittal

630 2004). A shelf life of up to 12 days can be achieved for groundfish products by maintaining

631 chilled temperatures $\left(1\right.$ to $\left.5^{\circ} \mathrm{C}\right)$ and employing good handling processes from catch to market

632 (Castell 1954; Olafsdóttir et al. 2006). The shelf-life can be extended to 15 days by super-

633 chilling to $-1.5^{\circ} \mathrm{C}$ immediately after harvest (Bayliss 1996; Dang et al. 2018a; Duun \& Rustad

634 2007; Olafsdóttir et al. 2006). Therefore, if landings cannot be processed, shipped, purchased,

635 and used by the end client within two weeks post catch, freezing, holding, and thawing the

636 product can extend the freshness by further slowing down microbial activity. To provide more

637 detail into the GVC for demersal species, fresh and frozen groundfish landings are summarized

638 in the following subsections.

639

640 Fresh groundfish landings: 
641 Post catch, the fish are bled and gutted onboard the fishing vessel to remove the natural enzymes 642 and help mitigate against autolytic degradation (Huss et al. 1995). The fish are then stored in the 643 vessel's hold or in pans using ice slurry or flake ice to keep it chilled and maintain freshness until 644 the processor receives them; thus, minimizing microbial degradation (Gram \& Dalgaard 2002).

645 Once landed, primary processing (heading, filleting, and skinning) occurs, and fillets are sold 646 into the fresh market. Secondary, value-added processing such as portioning, mincing, breading, 647 and consumer packaging may also follow at the same processor or in a different jurisdiction by a 648 lower-cost processor before being sold into the fresh market (Stringer et al. 2011).

649

650 The final product may also be frozen to slow down autolytic and microbiological degradation 651 and extend freshness (Benjakul \& Bauer 2000; Ghaly et al. 2010; Haugland 2002). Proper 652 freezing and cold storage will allow the product to be held and sold when demand and price are 653 higher or shipped long distances using low-cost ground transport to larger markets (Ziegler et al.

654 2013). Frozen fillets can also be sent to a secondary processor to complete the value-added work, 655 such as portioning, coating, or preparing ready-to-serve products. After processing, the fillets can 656 be sold as frozen or chilled refreshed (Mai et al. 2020). Today, much value-added work is 657 completed in developing countries to reduce costs, and final products can be refrozen and 658 shipped back (Stringer et al. 2011).

659

660 As shown in Figure 7, commercially harvested groundfish can be frozen multiple times along the

661 value chain. This process is termed "twice-frozen" or "double frozen" (Hedges 2002). This

662 repeated freezing and thawing can affect product quality if proper care is not taken (Fuentes et al.

663 2013; PrimeFish 2017; Washburn et al. 2017) and may result in dehydration, drip loss, and gaps 664 in the flesh (Dawson et al. 2018; Lorentzen et al. 2019; Tironi et al. 2010).

665

666

667 Groundfish is landed frozen primarily in offshore fisheries and regions with large commercial 668 fisheries and little vertical integration (PrimeFish 2017). Freezer trawlers land frozen products 669 with some degree of processing completed onboard. Frozen fillets or headed and gutted (H\&G)

670 products are produced quickly at sea post-catch to preserve the initial quality (Hedges 2002;

671 Norsworthy 2015).

672

673 Onboard processing has the distinct advantage of allowing the fish to go through Rigour-Mortis

674 (rigour) after processing occurs and the animals are frozen. Rigour is the binding of the

675 myofibrils' thick and thin filaments (Hedges 2002). This binding occurs through the coupling of

676 actin and myosin by consuming adenosine triphosphate as energy and results in the loss of

677 muscle extension (Yao et al. 2019). Peters et al. (1968) found that freezing fish pre-rigour

678 produced a higher quality product than freezing in- or post-rigour. However, Hedges (2002)

679 noted that if thawing occurs before rigour is complete, the fish may complete rigour during the

680 thawing process, which will result in excessive drip loss and damage to the flesh. 
681

682 After landing, the frozen product is shipped for secondary processing to low-cost countries. The

683 final products are refrozen and shipped to the end consumers (PrimeFish 2017; Stringer et al.

684 2011). Similar to fresh groundfish landings, frozen landings can be frozen and thawed several

685 times along the GVC. Therefore, proper freezing of groundfish along the GVC can reduce cost

686 and improve quality and yield.

687

688

\section{Pelagic species}

689 Pelagic species refer to fish that dwell and feed near the surface or the mid-water column

690 (Bender 2014b). Bayliss (1996) reported that because pelagic fish are more active than

691 groundfish, their flesh has a more aerobic metabolizing reddish hue, containing up to $35 \%$ lipids

692 and makes them a rich source of polyunsaturated fatty acids. Large, commercial, North Atlantic

693 pelagic fisheries include Bluefin tuna (Thunnus thynnus), Atlantic herring (Clupea harengus),

694 Atlantic mackerel (Scomber scombrus), Atlantic salmon (Salmo salar), European anchovy

695 (Engraulis encrasicolus), and Capelin (Mallotus villosus) (DFO 1980; DFO 2019a; ICES 2019;

696 National Marine Fisheries Service 2017; Norsworthy 2015). Pelagic fish are caught using seines,

697 trawls, drift nets, fish traps, and long-lines (Jennings et al. 2001; Montgomerie 2015). Atlantic

698 Salmon are also farmed by commercial aquaculture operations throughout the region (National

699 Marine Fisheries Service 2017; PrimeFish 2017).

700

701 Key pelagic species in North Atlantic fisheries such as tuna, herring, mackerel, and salmon are

702 harvested from wild capture and aquaculture fisheries (DFO 1980; DFO 2019a; National Marine

703 Fisheries Service 2017; PrimeFish 2017). Pelagic species can suffer from lipid oxidation, colour

704 change, colour fading, formaldehyde formation, and protein denaturation if not preserved

705 effectively (Nakazawa \& Okazaki 2020). Pelagics typically have higher lipid concentrations in

706 their flesh than groundfish, so rancidity due to oxidation can be a primary concern during cold

707 storage (Bayliss 1996; Devadason et al. 2016; Hedges 2002; Papuc et al. 2017). As a result,

708 many pelagics are traditionally preserved by salting, drying, smoking, pickling, and canning;

709 alternatively, salmon and herring are regularly frozen along the GVC (DFO 1980; PrimeFish

710 2017). More details into the GVC for pelagic fisheries, wild-capture and aquaculture fisheries are

711 presented in the following subsections.

712

713 Wild capture pelagic species:

714 Atlantic herring is one of the most abundant wild-capture pelagic fisheries by weight in the

715 North Atlantic and possesses a relatively simple GVC (DFO 2018a; Gudmundsson et al. 2006;

716 National Marine Fisheries Service 2017; PrimeFish 2017). Bayliss (1996) reported that pelagic

717 fish such as mackerel and herring only have a seven-day shelf life at refrigerated temperatures,

718 and as a result, preservation is necessary to maintain freshness.

719 
720 The primary markets for herring are Japan, Western Europe, and Africa (Gudmundsson et al.

721

722

723

724

725

726

727

728

729

730

731

732

733

734

735

736

737

738

739

740

741

742

743

744

745

746

747

748

749

750

751

752

753

754

755

756

757

758

759

2006). Over the past decade, consolidation within the European herring fishery has been due to the reduced prices paid for herring and reduced quotas (PrimeFish 2017). In North America, catches also declined, but these catches' value increased (National Marine Fisheries Service 2017). As a result, herring's Icelandic and Norwegian production is reduced to frozen fillets and whole, frozen, H\&G fish exported for sale or secondary processing elsewhere (PrimeFish 2017).

Processing of frozen Atlantic herring is presented in detail by Dang et al. (2018b), Hamre et al. (2003), and Tolstorebrov et al. (2014). Freezing herring extends the product's shelf life by slowing down autolytic and microbiological degradation (Benjakul \& Bauer 2000; Ghaly et al. 2010; Haugland 2002). Holding at very low temperatures minimizes colour change and fading (Bito 1976; Nakazawa \& Okazaki 2020). Care should be taken throughout the freezing and thawing process to maximize water holding capacity and minimize freezer burn, texture loss, and gaping (Dawson et al. 2018; Lorentzen et al. 2019). Like groundfish, rapid freezing minimizes ice crystal size and minimizes damage to the flesh (Dawson et al. 2018; Tironi et al. 2010). Prerigour freezing reduced thawing loss and oxidation better than in- and post-rigour freezing (Dang et al. 2018b), and cold-chain abuse must be avoided to maintain shelf-life. Hamre et al. (2003) noted that the dark muscle was three to four times more susceptible to oxidation than the light muscle and should be removed before freezing to improve quality. Tolstorebrov et al. (2014) also found that cold-storing herring at $-45^{\circ} \mathrm{C}$ inhibited oxidation compared to $-25^{\circ} \mathrm{C}$; he also found that vacuum packaging herring fillets in a medium oxygen barrier coupled with cold storage could produce similar results at $-25^{\circ} \mathrm{C}$. Pelagics, such as tuna, have high concentrations of myoglobin in their flesh which gives the meat a reddish hue; to prevent the oxidation of the myoglobin and subsequent loss of colour. Previous studies have shown that these species need to be cold stored at temperatures below $-35^{\circ} \mathrm{C}$ (Bito 1976; Nakazawa \& Okazaki 2020). Therefore, processing and freezing pelagic species pre-rigour, removing dark muscle during processing, cold storing at ultralow temperatures, and correct packaging selection can enhance the fillets' storage quality and improve yield.

\section{Pelagic aquaculture:}

Atlantic salmon is primarily an aquaculture fishery managed by large, vertically integrated, multinational corporations and is the largest pelagic fishery by value in the North Atlantic region (DFO 2018a; National Marine Fisheries Service 2017; PrimeFish 2017). The GVC for salmon is similar to groundfish; however, due to the full integration and enhanced processing technologies available, more secondary and value-added processing occurs before shipping (Miller, 2017; Norsworthy, 2015), minimizing the need for multiple freeze and thaw cycles. Most salmon produced by aquaculture companies are sent to the fresh market as whole, gutted, headed and gutted $(H \& G)$, fillets, portions and minced products. Some material is frozen and shipped to value-added processors elsewhere, e.g., frozen salmon portions produced in the Faroe Islands for European and US markets (PrimeFish 2017).

PeerJ reviewing PDF | (2021:06:62561:1:0:NEW 12 Oct 2021) 
761 Alizadeh et al. (2007), Dawson et al. (2018), and Sigurgisladottir et al. (2000) discussed

762

763

764

765

766

767

768

769

770

771

772

773

774

775

776

777

778

779

780

781

782

783

784

785

786

787

788

789

790

791

792

793

794

795

796

797

798 processing frozen Atlantic salmon in detail. The colour change and weight loss found in frozen and thawed salmon were downsides of freezing and occurred because of damage to the cellular structure (Alizadeh et al. 2007; Dawson et al. 2018). Faster freezing rates reduced this damage. Dawson et al. (2018) also reported that oxidation increases with cold storage time. Alizadeh et al. (2007); Dawson et al. (2018) reported freezing as a vital preservation method to extend the shelf life of salmon. The authors also noted that increasing the freezing rate increased the number of nucleation points, reduced the ice crystals' size, and produced a higher quality frozen product with less drip loss, better texture, and protein stability. Unlike many other pelagic species, Atlantic salmon demonstrated slight quality deterioration when stored at $-25^{\circ} \mathrm{C}$ vs. $-40^{\circ} \mathrm{C}$, and special packaging has been shown to improve product quality (Indergård et al. 2014). Alizadeh et al. (2007) found that more, smaller ice crystals were produced when high-pressure processing (HPP) was used in conjunction with freezing and thawing resulting in even less drip loss.

Therefore, the quality and yield of frozen and thawed salmon can be improved by increasing the freezing rate in conjunction with using HPP. Minimizing the time expended in cold storage reduces colour change and rancidity due to oxidation.

\section{Shellfish species}

Shellfish refers to a wide range of marine mollusks, echinoderms and crustaceans (Bender 2014c). Lipid content is $0.8-2.3 \%$ in mollusks and $0.8-6.7 \%$ in crustaceans such as shrimp, lobster and crab (Newcombe 1944; Sirot et al. 2008). Large, commercial, North Atlantic shellfish fisheries include American lobster (Homarus americanus), Snow crab (Chionoecetes opilio), Dungeness crab (Metacarcinus magister), Orange-footed sea cucumber (Cucumaria frondosa), Atlantic sea scallops (Placopecten magellanicus), Atlantic surf clams (Spisula solidissima), Hard clams (Mercenaria mercenaria), Blue mussels (Mytilus edulis), Atlantic white shrimp (Litopenaeus setiferus), and Northern shrimp (Pandalus borealis) (DFO 2018b; DFO 2019b; National Marine Fisheries Service 2017; PrimeFish 2017). Crustaceans such as lobster and crab are typically caught using baited traps or pots; shrimp are caught using beam-trawls (Montgomerie 2015). Marine mollusks such as clams, oysters, mussels and scallops, and echinoderms such as sea cucumber are typically harvested using a dredge (Montgomerie 2015). The annual global production of marine bivalves for human consumption is 15 million tonnes, with $89 \%$ farmed in commercial aquaculture operations (Wijsman et al. 2019).

Key shellfish species in the North Atlantic fishery include lobster, crab, shrimp, sea cucumbers, scallops, clams, and mussels. Shellfish are reported to have a wide range of lipid concentrations depending on species (Newcombe 1944; Sirot et al. 2008; Zhong et al. 2007), so oxidation is still a challenge and must be considered when held in cold storage. 
799 Shellfish are typically landed live, processed, and shipped to market. Crustaceans and mollusks

800 can be processed and sold live, cooked, or frozen (National Marine Fisheries Service 2017;

801 Norsworthy 2015; Sherstneva 2013); echinoderms are typically sold cooked and frozen, smoked,

802 or dried (Zhong et al. 2007). Frozen shellfish can be retailed or shipped for secondary processors

803 elsewhere (Stringer et al. 2011). The impact of freezing and thawing on the GVC for shellfish,

804 mollusks, echinoderms, and crustaceans is presented in the following subsections.

805

806

807 Mollusks such as scallops, mussels and clams are landed live and processed. Khan \& Liu (2019)

808 reported that freezing has a limited impact on mollusks' shelf life. Therefore, processors must

809 combine freezing with other thermal treatments, modified atmospheric packaging (MAP) and

810 HPP for long-term storage. This process is necessary to improve microbial safety, minimize

811 spoilage, and maintain the product's fresh flavour (Narwankar et al. 2011). Like finfish, care

812 must be taken during freezing and thawing to mitigate the damage caused by cold chain abuse

813 and reduce hold times in cold storage to reduce oxidation (Baker 2016).

814

815 Echinoderms:

816 Echinoderms, such as sea cucumbers, are considered an essential food in the Indo-Pacific region

817 because of their antioxidant and medicinal properties (Zhong et al. 2007). Sea cucumber, for

818 example, is landed live, gutted to minimize autolytic and microbiological spoilage, and

819 processed for sale. Processing consists of cooking, drying, smoking, packaging and freezing

820 (Zhong et al. 2007). Frozen product is shipped to Southeast Asia markets where it is either sold

821 frozen or thawed for secondary processing. Again, care must be taken during freezing and

822 thawing to minimize cold chain abuse.

823

824

825

826

827

828

829

830

831

832

833

834

\section{Crustaceans:}

Crustaceans such as lobster, crab and shrimp are high-value species in many North Atlantic fisheries (National Marine Fisheries Service 2017; Norsworthy 2015; Sherstneva 2013; Steneck et al. 2011). Shrimp are primarily landed fresh or frozen (DFO 2018a). Once landed, they are cooked, peeled, frozen, and packaged or canned (DFO 2018a; National Marine Fisheries Service 2017; Norsworthy 2015). Lobster and crab are landed live due to their short shelf-life and sold live or cooked and frozen. Crab processing includes butchering, cooking, chilling, freezing, packaging, and cold storing; frozen lobster is almost identical (National Marine Fisheries Service 2017; Norsworthy 2015). Freezing is a valuable preservation technique for crustaceans. Immersion freezing is the primary method to rapidly reduce the product from its cooking

835 temperature $\left(80^{\circ} \mathrm{C}\right.$ to $\left.90^{\circ} \mathrm{C}\right)$ to $-18^{\circ} \mathrm{C}$ quickly to maintain quality. However, like other species, freezing and frozen storage may lead to the denaturation of the myofibrillar proteins, resulting in

837 textural changes such as reduced juiciness and water holding capacity (Lorentzen et al. 2019). 838 
839 Summary of freezing and thawing on commercial North Atlantic seafood species

840 The merits and detractions of freezing and thawing of commercial North Atlantic Seafood

841 species are summarized in Table 5.

842

843

844

Assessment of the Newfoundland and Labrador Cod Fishery

845 Declining shellfish stocks

846

The fishing industry in Newfoundland and Labrador is in transition. Fisheries and Oceans

847 Canada (DFO) reported that Northern shrimp (Pandalus borealis), Striped shrimp (Pandalus

848 montagui), and Snow crab (Chinoecetes opilio) stocks, which have supported the local fishing

849 industry since the collapse of the groundfish stocks, are declining due to intense fishing pressures

850 and climate change (DFO 2014; DFO 2016; DFO 2017a; DFO 2021b; DFO 2021c). Recent DFO surveys estimated crab biomass (except for the North Atlantic Fisheries Organization (NAFO) Divisions 2H and 2J (Fig. 8)) and reported stocks remain near historic low levels (DFO 2021b) while multispecies trawl surveys by DFO (2017a); DFO (2021c) indicated a significant decline

854 in Northern shrimp and Striped shrimp fishable biomass indexes. These declines have resulted in 855 recent cuts to crab and shrimp quotas for Newfoundland and Labrador processors and harvesters.

While cold water species stocks declined, DFO (2017b) reported that the Northern cod stock total biomass increased from $9.8 \mathrm{kt}$ in 1995 to $481.3 \mathrm{kt}$ in 2016 in NAFO Divisions $2 \mathrm{~J}$, 3K and 3L (Fig. 8). DFO (2019b); DFO (2021a) also reported that the spawning stock biomass (SSB) increased to $398 \mathrm{kt}$ in 2019; however, it still only represents $48 \%$ of the limit reference point

861 established by DFO (2011) and in the critical range. A sizeable commercial fishery is potentially

862 still a decade away (CCFI 2017); however, the industry needs to prepare now for its future

863 success. Therefore, it is necessary to assess the readiness of Newfoundland and Labrador's

864 fisheries to re-enter the cod supply chain as a significant global supplier and generate the best

865 value from these limited resources to help grow the provincial economy.

\section{Challenges for rebounding cod stocks}

Since the Minister of Fisheries declared a moratorium on the Northern cod fishery in NAFO

869 Divisions 2J, 3K, and 3L on July 2, 1992 (Crosbie 1992), there have been significant changes in the global market for whitefish. Cod block was the primary product for the Newfoundland and Labrador processors before the moratorium, and it was used to manufacture breaded, battered, and frozen products such as fish sticks and other low-end products. Since 1992, cod block has mostly been replaced by Alaskan Pollock and cod block produced as a by-product from processing cod fillets (i.e. trimming discards and poor-quality fillets) (Tonkovitch 2017; Verge 2017). Furthermore, the mid-grade white fish product market (quick service and casual dining

876 establishments) is primarily being supplied using Pollock (Tonkovitch 2017) and twice-frozen whitefish fillets processed in China, Vietnam and Lithuania (Hedges 2002; PrimeFish 2017; pangasius catfish and tilapia (Verge 2017). Therefore, local processors have limited export 
879 options and should focus on the high-end, fresh market driven by consumers looking for high880 quality, fresh products with extended shelf lives (Ashie et al. 1996). Iceland's cod fishery 881 currently dominates this market for fresh cod products; however, successfully penetrating this 882 market will allow the Newfoundland and Labrador industry to earn the most value from its cod 883 resources.

884

885 Therefore, Newfoundland and Labrador cod harvesters and processors need to evaluate strategies 886 to penetrate the high-end market and maximize the value from the limited Northern cod 887 resources by providing a timely and high-quality product to the market (Brown 2018). However, 888 before Newfoundland and Labrador processors can enter this market, several challenges first 889 need to be mitigated to maximize the value of Atlantic cod, including: (a) Newfoundland's cod 890 fishery is dominated by small, inshore boats with limited space for ice production or ice storage 891 (NL-GIDC 2017); (b) the peak fishing season for these small vessels is roughly four months-long 892 between May and September (NL-GIDC 2017) and does not correspond with the peak consumer 893 demand (Lent: typically, February-April), which reduces stakeholder value (Sackton 2014); and 894 (c) Newfoundland is an island in the North Atlantic with limited, timely options for commercial 895 transportation of fresh product to national and international markets. Furthermore, the weather 896 during the winter is dominated by strong winds, heavy precipitation, and intense fog. These 897 extreme weather conditions further limit commercial transportation reliability during the winter 898 when the demand and price for cod are highest. Therefore, until the industry can effectively deal 899 with the space and time logistical challenges mentioned above, Newfoundland and Labrador 900 processors can expect to supply frozen cod to the market (Brown 2018). The supply of frozen 901 fillets results in a fourth challenge (d) the price paid for frozen cod fillets is approximately half compared to fresh cod fillets, as shown in Figure 9 (Sackton 2014) due to the perceived and actual reduction in sensory quality discussed in earlier sections.

904

\section{Employing freezing and thawing to improve quality}

When done correctly, freezing and thawing cod fillets will increase shelf life, improve food safety, reduce shipping costs, and level out the seasonal variabilities between supply and demand (Backi 2015; Haugland 2002; NL-GIDC 2017; Torry Research Station 1977). However, coldchain abuse and improper freezing and thawing techniques will result in quality defects, including protein denaturation, oxidation, poor colour and texture, and freezer burn, which will result in the deterioration of the fillet quality (Chevalier et al. 2000; Frelka et al. 2019; Leygonie

913

914 et al. 2012; Nakazawa \& Okazaki 2020).

915

Jensen et al. (2010) reported that a chilled product (frozen and thawed) could receive higher prices than a frozen product if the quality of the chilled product closely resembles a fresh

916

917 product. Therefore, value can be maximized by: (a) employing processes that improve freezing rates and minimize ice crystal size, (b) minimize protein denaturation and oxidation during cold storage, (c) minimize the number of freeze-thaw cycles, and (d) effectively manage the cold 
919 chain throughout the entire GVC. Hence, Newfoundland and Labrador processors could employ 920 these principles: (a) to produce a high-quality frozen product, (b) hold it until demand and price

921 improve, (c) transport product to larger markets using lower-cost ground transportation, (d) thaw

922 the products using highly controlled processes and (e) sell them during peak season as chilled

923 which will command a price closer to fresh.

924

925 Freezing and thawing foodstuffs can be divided into three phases: freezing, cold storage and 926 thawing (Hanenian \& Mittal 2004). As discussed earlier, freezing occurs when a product 927 undergoes a phase change from liquid to solid. Typical freezing methods employed by 928 Newfoundland cod processors act on the boundary and include air blast, plate, immersion, and 929 tunnel freezing. Spray and cryogenic freezing are also popular boundary methods (Torry 930 Research Station 1977); however, restricted in Newfoundland due to the scarcity and cost of 931 liquified gasses. Local seafood processors do not use instantaneous methods such as magnetic, 932 pressure, and cell alive freezing, and these systems will not be considered further. Therefore, 933 given these limitations, to improve the quality of frozen cod fillets, processors need to: (a) 934 employ rapid freezing techniques to minimize ice crystal size and subsequent damage to the 935 cellular structure; (b) store product below $-30^{\circ} \mathrm{C}$ to minimize oxidation and protein denaturation; 936 and (c) minimize cold chain abuse during the holding and transport phases.

937

938 As discussed above, thawing is the addition of heat to raise the product's temperature and enables 939 the subsequent phase change from a solid to a liquid (Backi 2015; Haugland 2002; Reid 1993).

940 Again, thawing methods fall into two main categories: methods through the boundary and 941 methods acting on the inner domain (Backi 2015; Haugland 2002). Thawing methods typically 942 employed by local processors act on the boundary and include thawing in air and water. Other 943 thawing methods that act on the boundary include vacuum and contact thawing; however, they 944 are not typically used locally in Newfoundland and Labrador. Methods acting on the inner 945 domain include ultra-high pressure, dielectric, electrical resistance and microwave (Backi 2015).

946 Local fish processors do not use freezing methods acting on the inner domain. Therefore, to 947 improve the quality of thawed products: (a) thawing should not take place until the product is 948 entirely out of rigour; (b) thawing methods should be rapid and employ circulation of the 949 thawing medium to minimize dehydration; (c) thawing methods should not promote the growth 950 of microorganisms; and (d) thawing methods can employ ultrahigh pressure to maximize the 951 quality parameters.

952

953

954

955

956

957

958

\section{Summary}

There has been considerable research into the spoilage mechanisms and subsequent preservation of seafood (Cheng et al. 2014; Ghaly et al. 2010; Persson \& Löndahl 1993; Seremeti 2007; Suh et al. 2017). The spoilage of seafood is broken down into three phases: autolytic degradation, bacterial spoilage, and oxidation (Ghaly et al. 2010; Huss et al. 1995; Surette et al. 1988; Tull 1996). Autolysis is responsible for textural changes to the flesh and degradation of freshness 
959

960

961

962

963

964

965

966

967

968

969

970

971

972

973

974

975

976

977

978

979

980

981

982

983

984

985

986

987

988

989

990

991

992

993

994

995

996

997

998

with little microbial change (Benjakul \& Bauer 2000; Gram \& Huss 1996; Haugland 2002;

Surette et al. 1988). Microbial spoilage typically follows autolysis and may degrade taste, colour, odour, texture, and juiciness. Microbial degradation in seafood also results in products that are not fit for human consumption leading to unnecessary waste (Cheng et al. 2014; Ghaly et al. 2010; Gram \& Dalgaard 2002). Lastly, seafood held in cold storage for an extended period or at temperatures that are not sufficiently low can suffer from oxidation, especially if lipid content in the product is high (Ghaly et al. 2010; Kolanowski et al. 2007; Nakazawa \& Okazaki 2020; Papuc et al. 2017).

Seafood is at its peak freshness immediately after death and must be preserved quickly to maintain its freshness (Huss et al. 1974; Lakshmanan 2000; Warrier et al. 1975). Preservation entails slowing down the food spoilage process, and humans have been preserving food for centuries (Kaloyereas 1950; Vaclavik \& Christian 2014). Conventional preservation techniques used by the seafood industry include salting, drying, smoking, pickling, canning, heating, fermenting, chilling and freezing; some that affect the organoleptic properties of the product while others maintain the fresh taste of the food such as freezing and thawing (Alizadeh et al. 2007; Gonçalves et al. 2012; Torry Research Station 1977). The primary gap identified by this review is much of the research into freezing and thawing methods is limited to novel methods (Cai et al. 2019; Li \& Sun 2002; Wu et al. 2017) or small-scale studies (Baygar \& Alparslan 2015; Cai et al. 2020; Espinoza Rodezno et al. 2013) with little research directed at fullscale, processing applications (Svendsen et al. 2022). Another gap identified is the use of uncontrolled thawing methods (Haugland 2002) by industry and the relative lack of thawing research compared to freezing (Fig 4).

Therefore, employing freezing and thawing throughout the value chain is an effective method to preserve seafood. As discussed, the GVC for demersal, pelagic and shellfish species is similar to freezing and thawing after primary processing, secondary processing and throughout the distribution chain to maintain freshness and quality. In higher lipid content pelagic species, freezing may be coupled with other preservation methods such as advanced packaging, salting and pickling to minimize oxidation. In mollusks, specifically bivalves, freezing alone is not an effective preservation technique and may be coupled with HPP and specialized packaging.

For the specific case of Northern cod with consideration to a re-emerging Newfoundland and Labrador cod fishery, the primary concerns identified were: (a) the seasonality of the fishery and its disconnect from peak demand, (b) distance between the harvesting and processing locations and potential markets, (c) potential weather disruptions affecting the transport of the final product and d) Newfoundland and Labrador's ability to penetrate the high-end market by providing a product that closely resembles fresh. Optimized freezing and thawing methods allow processors to (a) process, freeze, and cold store cod products during the fishing season to be sold when demand and value are higher; (b) ship the frozen product to a distribution center near major 
999 markets using cheaper refrigerated ground transportation; (c) thaw fillets to meet the demand

1000 using an optimized process; and (d) sell product to high-end restaurants and seafood shops as a

1001 chilled product, which will command a price closer to fresh. These markets can be attained by (a)

1002 employing high-speed freezing techniques that minimize ice crystal size and subsequent damage

1003 to the flesh combined with ultralow temperature cold storage and transportation to maintain

1004 product quality until needed; and (b) optimizing the cold chain with thawing methods that thaw

1005 the product quickly while minimizing dehydration, damage to cells and subsequent drip loss

1006 (Persson \& Löndahl 1993; Seremeti 2007; Suh et al. 2017). Implementing the above practices

1007 will allow processors to produce a chilled product that closely resembles a fresh fillet and can be

1008 sold to high-end restaurants and retailers and enable the local seafood industry to earn more

1009 value for a frozen-thawed cod product by commanding prices similar to fresh fillets.

1010

1011 Acknowledgements

1012 The authors would like to thank Mr. Robert Verge and Dr. Leonard Lye for their valuable

1013 suggestions during the preparation of this manuscript.

1014

1015 References

1016 Alasalvar C, Taylor KDA, Öksüz A, Shahidi F, and Alexis M. 2002. Comparison of Freshness

1017

1018

1019

1020

1021

1022

1023

1024

1025

1026

1027

1028

1029

1030

1031

1032

1033

1034

1035

1036

1037

1038

1039

1040 Quality of Cultured and Wild Sea Bass (Dicentrarchus labrax). Journal of Food Science 67:3220-3226. 10.1111/j.1365-2621.2002.tb09569.x

Alizadeh E, Chapleau N, De Lamballerie M, and Lebail A. 2007. Effects of freezing and thawing processes on the quality of Atlantic salmon (Salmo salar) fillets. Journal of Food Science 72:E279-E284. 10.1111/j.1750-3841.2007.00355.x

Almy LH, and Field E. 1921. The preservation of fish frozen in chilled brine. I-The penetration of salt. Journal of industrial and engineering chemistry 13:927-930. 10.1021/ie50142a024

Appel SK. 1990. Artificial refrigeration and the architecture of 19th-century American breweries. The Journal of the Society for Industrial Archeology 16:21-38.

Archer M, Edmonds M, and George M. 2008. Seafood Thawing. U.K.: Seafish Research \& Development Dept.

Ashie IN, Smith JP, and Simpson BK. 1996. Spoilage and shelf-life extension of fresh fish and shellfish. Crit Rev Food Sci Nutr 36:87-121. 10.1080/10408399609527720

Backi CJ. 2015. Modeling, Estimation and Control of Freezing and Thawing Processes: Theory and Applications (Doctoral Thesis). Norwegian University of Science and Technology.

Backi CJ. 2018. Methods for (industrial) thawing of fish block: A review. Journal of Food Process Engineering 41:1-11.

Badii F, and Howell NK. 2002. Changes in the texture and structure of cod and haddock fillets during frozen storage. Food hydrocolloids 16:313-319. 10.1016/S0268-005X(01)00104-7

Baker GL. 2016. Food safety impacts from post-harvest processing procedures of molluscan shellfish. Foods 5:12. 10.3390/foods5020029

Baygar T, and Alparslan Y. 2015. Effects of multiple freezing $\left(-18 \pm 2{ }^{\circ} \mathrm{C}\right)$ and microwave thawing cycles on the quality changes of sea bass (Dicentrarchus labrax). Journal of Food Science and Technology 52:3458-3465. 10.1007/s 13197-014-1373-z 
1042 Bayliss P. 1996. Chemistry in the kitchen: Fish and fish products. Nutrition \& Food Science

1043

1044

1045

1046

1047

1048

1049

1050

1051

1052

1053

1054

1055

1056

1057

1058

1059

1060

1061

1062

1063

1064

1065

1066

1067

1068

1069

1070

1071

1072

1073

1074

1075

1076

1077

1078

1079

1080

1081

1082

1083

1084

1085

1086 96:41-43. 10.1108/00346659610105897

Bender DA. 2014a. Demersal fish. A Dictionary of Food and Nutrition. 4th ed: Oxford University Press.

Bender DA. 2014b. Pelagic fish. A Dictionary of Food and Nutrition. 4th ed: Oxford University Press.

Bender DA. 2014c. Shellfish. A Dictionary of Food and Nutrition. 4th ed: Oxford University Press.

Benjakul S, and Bauer F. 2000. Physicochemical and enzymatic changes of cod muscle proteins subjected to different freeze-thaw cycles. Journal of the Science of Food and Agriculture 80:1143-1150.

Benjakul S, and Visessanguan W. 2010. Impacts of freezing and frozen storage on quality changes of seafoods. In: Devahastin S, ed. Physicochemical Aspects of Food Engineering and Processing. Boca Raton, FL: CRC Press, 283-306.

Biodeterioration. 2006. Biodeterioration. In: Singleton P, and Sainsbury D, eds. Dictionary of Microbiology \& Molecular Biology. 3rd ed. Hoboken, NJ: John Wiley and Sons.

Bito M. 1976. Studies on the retention of meat color of frozen tuna. Bull Tokai Reg Fish Res Lab 84:51-113.

Bøknæs N, Østerberg C, Nielsen J, and Dalgaard P. 2000. Influence of freshness and frozen storage temperature on quality of thawed cod fillets stored in modified atmosphere packaging. LWT - Food Science and Technology 33:244-248.

Boonsumrej S, Chaiwanichsiri S, Tantratian S, Suzuki T, and Takai R. 2007. Effects of freezing and thawing on the quality changes of tiger shrimp (Penaeus monodon) frozen by airblast and cryogenic freezing. Journal of Food Engineering 80:292-299. 10.1016/j.jfoodeng.2006.04.059

Brown P. 2018. Positive impact of new technology on the North Atlantic cod fishery. Navigator 21:67-68.

Cai L, Cao M, Regenstein J, and Cao A. 2019. Recent Advances in Food Thawing Technologies. Comprehensive Reviews in Food Science and Food Safety 18:953-970. https://doi.org/10.1111/1541-4337.12458

Cai L, Wan J, Li X, and Li J. 2020. Effects of different thawing methods on conformation and oxidation of myofibrillar protein from largemouth bass (Micropterus salmoides). Journal of Food Science 85:2470-2480. 10.1111/1750-3841.15336

Castell C. 1954. Spoilage Problems in Fresh Fish Production. In: Canada FRBo, editor. Ottawa. p 35.

Castell C, and Anderson G. 1948. Bacteria associated with spoilage of cod fillets. Journal of the Fisheries Board of Canada 7b:370-377.

CCFI. 2017. Workshop proceedings. In: CCFI, editor. Cod: Building the fishery of the future. Gander, NL.

Cheng JH, Sun DW, Han Z, and Zeng XA. 2014. Texture and structure measurements and analyses for evaluation of fish and fillet freshness quality: a review. Comprehensive Reviews in Food Science and Food Safety 13:10.

Chevalier D, Le Bail A, Chourot JM, and Chantreau P. 1999. High Pressure Thawing of Fish (Whiting): Influence of the Process Parameters on Drip Losses. Food science \& technology 32:25-31. 10.1006/fstl.1998.0500 
1087 Chevalier D, Sequeira-Munoz A, Le Bail A, Simpson BK, and Ghoul M. 2000. Effect of freezing

1088

1089

1090

1091

1092

1093

1094

1095

1096

1097

1098

1099

1100

1101

1102

1103

1104

1105

1106

1107

1108

1109

1110

1111

1112

1113

1114

1115

1116

1117

1118

1119

1120

1121

1122

1123

1124

1125

1126

1127

1128

1129

1130

1131 conditions and storage on ice crystal and drip volume in turbot (Scophthalmus maximus): Evaluation of pressure shift freezing vs. air-blast freezing. Innovative Food Science and Emerging Technologies 1:193-201. 10.1016/S1466-8564(00)00024-2

Connell JJ. 1980. Control of Fish Quality. Farnham, UK: Fishing News Books, Ltd.

Coolnova. n.d. Coolnova ${ }^{\circledR}$ Freshness Protection. Available at http://coolnova.org/index.html (accessed January 20 2018).

Crosbie J. 1992. Notes for a statement by the Honourable John C. Crosbie, Minister of Fisheries and Oceans and Minister for the Atlantic Canada Opportunities Agency on income support and related measures for fishermen and plant workers affected by the northern (2J3KL) cod moratorium, St. John's, Newfoundland. Ottawa: Ottawa : Dept. of Fisheries and Oceans.

Cui Y, Xuan X, Ling J, Liao X, Zhang H, Shang H, and Lin X. 2019. Effects of high hydrostatic pressure-assisted thawing on the physicohemical characteristics of silver pomfret (Pampus argenteus). Food Science \& Nutrition 7:1573-1583. 10.1002/fsn3.966

Dang HTT, Gudjónsdóttir M, Karlsdóttir MG, Nguyen M, Tómasson T, and Arason S. 2018a. Stability of Golden redfish (Sebastes marinus) during frozen storage as affected by raw material freshness and season of capture. Food Science \& Nutrition 6:1065-1076. $10.1002 /$ fsn 3.648

Dang HTT, Gudjónsdóttir M, Ren D, Karlsdóttir MG, Minh VN, Tómasson T, and Arason S. 2018b. Effects of pre and postrigor freezing and temperature stress during frozen storage on physicochemical stability of Atlantic herring (Clupea harengus) muscle. Journal of Food Processing and Preservation 42. 10.1111/jfpp. 13754

Dawson P, Al-Jeddawi W, and Remington N. 2018. Effect of freezing on the shelf life of salmon. International Journal of Food Science 2018. 10.1155/2018/1686121

de Alba M, Pérez-Andrés JM, Harrison SM, Brunton NP, Burgess CM, and Tiwari BK. 2019. High pressure processing on microbial inactivation, quality parameters and nutritional quality indices of mackerel fillets. Innovative Food Science and Emerging Technologies 55:80-87. 10.1016/j.ifset.2019.05.010

Dempsey P, and Bansal P. 2012. The art of air blast freezing: Design and efficiency considerations. Applied thermal engineering 41:71-83. 10.1016/j.applthermaleng.2011.12.013

Devadason C, Jayasinghe C, Sivakanesan R, Senarath S, Beppu F, and Gotoh N. 2016. Comparative analysis of lipid content and fatty acid composition of commercially important fish and shellfish from Sri Lanka and Japan. Journal of oleo science 65:543556. $10.5650 /$ jos.ess 16056

DFO. 1980. Atlantic "pelagic" fish. Ottawa: Department of Fisheries and Oceans. Communications, Branch.

DFO. 2011. Proceedings of the Newfoundland and Labrador Regional Atlantic Cod Framework Meeting: Reference Points and Projection Methods for Newfoundland Cod Stocks; November 22-26, 2010. Ottawa: Fisheries and Oceans Canada.

DFO. 2014. Short-Term Stock Prospects for Cod, Crab and Shrimp in The Newfoundland and Labrador Region (Divisions 2J3KL). Ottawa: Fisheries and Oceans Canada.

DFO. 2016. Assessment of Newfoundland and Labrador (Divisions 2HJ3KLNOP4R) Snow Crab. In: Secretariat CSA, editor. Newfoundland and Labrador Region.

Peer] reviewing PDF | (2021:06:62561:1:0:NEW 12 Oct 2021) 
1132 DFO. 2017a. An Assessment of Northern Shrimp (Pandalus borealis) in Shrimp Fishing Areas

1133

1134

1135

1136

1137

1138

1139

1140

1141

1142

1143

1144

1145

1146

1147

1148

1149

1150

1151

1152

1153

1154

1155

1156

1157

1158

1159

1160

1161

1162

1163

1164

1165

1166

1167

1168

1169

1170

1171

1172

1173

1174

1175

1176
4-6 and of Striped Shrimp (Pandalus montagui) in Shrimp Fishing Area 4 in 2016. In:

Secretariat CSA, editor. Newfoundland and Labrador Region.

DFO. 2017b. Northern (NAFO Divs. 2J3KL) Cod Stock Update. In: Secretariat CSA, editor. Newfoundland and Labrador Region.

DFO. 2018a. 2017 Atlantic Coast Commercial Landings, By Region. Available at https://www.dfo-mpo.gc.ca/stats/commercial/land-debarq/sea-maritimes/s2017aveng.htm (accessed November 25 2019).

DFO. 2018b. Northern shrimp and striped shrimp - shrimp fishing areas 0, 1, 4-7, the Eastern and Western Assessment Zones and North Atlantic Fisheries Organization (NAFO) Division 3M. Ottawa: Fisheries and Oceans Canada.

DFO. 2019a. Atlantic and Arctic commercial fishing. Available at https://www.dfompo.gc.calfisheries-peches/commercial-commerciale/atl-arc/index-eng.html.

DFO. 2019b. Canada's Fisheries Fast Facts 2018. Ottawa: Fisheries and Oceans Canada.

DFO. 2021a. 2020 stock status update for Northern cod. In: Secretariat CSA, editor. Newfoundland and Labrador Region: Fisheries and Oceans Canada.

DFO. 2021b. Assessment of Newfoundland and Labrador (Divisions 2HJ3KLNOP4R) Snow Crab. In: Secretariat CSA, editor. Newfoundland and Labrador Region: Fisheries and Oceans Canada.

DFO. 2021c. An Assessment of Northern Shrimp (Pandalus borealis) in Shrimp Fishing Areas 4-6 in 2019. In: Secretariat CSA, editor. St. John's, NL: Fisheries and Oceans Canada.

Dinçer T, Cadun A, Çaklı Ş, and Tolasa Ş. 2009. Effects of different thawing methods on the freshness quality of fish. Su Ürünleri Dergisi 26:253-256.

Duun AS, and Rustad T. 2007. Quality changes during superchilled storage of cod (Gadus morhua) fillets. Food chemistry 105:1067-1075.

Espinoza Rodezno LA, Sundararajan S, Solval KM, Chotiko A, Li J, Zhang J, Alfaro L, Bankston JD, and Sathivel S. 2013. Cryogenic and air blast freezing techniques and their effect on the quality of catfish fillets. Food science \& technology 54:377-382. 10.1016/j.lwt.2013.07.005

FAO \& WHO. 1980. Recommended international code of practice for frozen fish. FAO / WHO Codex Alimentarius Commission: CAC/RCP 16:58.

FAO \& WHO. 2020. Code of Practice for Fish and Fishery Products. Rome: Food and Agriculture Organization of the United Nations and World Health Organization.

Fellows PJ. 2016. Freezing. Food Processing Technology: Principles and Practice. 4th ed. Cambridge: Elsevier Science \& Technology, 885-928.

Frankel EN. 1985. Chemistry of free radical and singlet oxidation of lipids. Progress in Lipid Research 23:197-221.

Frelka J, Phinney D, Yang X, Knopp M, Heldman D, Wick M, and Vodovotz Y. 2019. Assessment of chicken breast meat quality after freeze/thaw abuse using magnetic resonance imaging techniques. Journal of the Science of Food and Agriculture 99:844853.

Fuentes A, Masot R, Fernández-Segovia I, Ruiz-Rico M, Alcañiz M, and Barat JM. 2013. Differentiation between fresh and frozen-thawed sea bream (Sparus aurata) using impedance spectroscopy techniques. Innovative Food Science and Emerging Technologies 19:210-217. 10.1016/j.ifset.2013.05.001 
1177 Garthwaite GA. 1997. Chilling and freezing of fish. In: Hall GM, ed. Fish Processing

1178 Technology. 2nd ed. London: Blackie Academic \& Professional, 93-118.

1179

1180

1181

1182

1183

1184

1185

1186

1187

1188

1189

1190

1191

1192

1193

1194

1195

1196

1197

1198

1199

1200

1201

1202

1203

1204

1205

1206

1207

1208

1209

1210

1211

1212

1213

1214

1215

1216

1217

1218

1219

1220

1221

Garthwaite GA. 1999. Fish raw material. In: Footitt R, and Lewis A, eds. The canning of fish and meat. 1st ed. London: Blackie Academic \& Professional, 17-43.

Ghaly AE, Dave D, Budge S, and Brooks MS. 2010. Fish spoilage mechanisms and preservation techniques: Review. American Journal of Applied Sciences 7:859-877.

Gonçalves A, Nielsen J, and Jessen F. 2012. Quality of frozen fish. In: Nollet LML, ed. Handbook of Meat, Poultry and Seafood Quality. Oxford, UK: Blackwell Publishing Ltd., 479-509.

Graiver N, Pinotti A, Califano A, and Zaritzky N. 2009. Mathematical modeling of the uptake of curing salts in pork meat. Journal of Food Engineering 95:533-540.

Gram L, and Dalgaard P. 2002. Fish spoilage bacteria - problems and solutions. Current Opinion in Biotechnology 13:262-266.

Gram L, and Huss HH. 1996. Microbiological spoilage of fish and fish products. International Journal of Food Microbiology 33:121-137. 10.1016/0168-1605(96)01134-8

Gudmundsson E, Asche F, and Nielsen M. 2006. Revenue Distribution Through the Seafood Value Chain. Rome: Food and Agriculture Organization of the United Nations.

Hamre K, Lie Ø, and Sandnes K. 2003. Development of lipid oxidation and flesh colour in frozen stored fillets of Norwegian spring-spawning herring (Clupea harengus L.). Effects of treatment with ascorbic acid. Food chemistry 82:447-453. 10.1016/S03088146(03)00070-0

Hanenian R, and Mittal GS. 2004. Effect of freezing and thawing on meat quality. JOURNAL OF FOOD AGRICULTURE AND ENVIRONMENT 2:74-80.

Haugland A. 2002. Industrial Thawing of Fish - To Improve Quality, Yield and Capacity (Doctoral Thesis). Norwegian University of Science and Technology.

Hedges N. 2002. Maintaining the quality of frozen fish. In: Bremner HA, ed. Safety and Quality Issues in Fish Processing. Boca Raton, FL: CRC Press, 379-406.

Huss HH, Borresen T, Dalgaard P, Gram L, Jensen B, Jorgensen B, Nielsen J, Baek Olsen K, Gill T, and Lupin HM. 1995. Quality and quality changes in fresh fish. Rome.

Huss HH, Dalsgaard D, Hansen L, Ladefoged H, Pedersen A, and Zittan L. 1974. The influence of hygiene in catch handling on the storage life of iced cod and plaice. International Journal of Food Science \& Technology 9:213-221.

ICES. 2019. North Western Working Group (NWWG). ICES Scientific Reports 1:826. doi.org/10.17895/ices.pub.5298

Indergård E, Tolstorebrov I, Larsen H, and Eikevik TM. 2014. The influence of long-term storage, temperature and type of packaging materials on the quality characteristics of frozen farmed Atlantic Salmon (Salmo Salar). International Journal of Refrigeration 41:27-36. 10.1016/j.ijrefrig.2013.05.011

Indzere Z, Manzano Martinez KD, Bezrucko T, Khabdullina Z, Veidenbergs I, and Blumberga D. 2020. Energy Efficiency Improvement in Thawing. Environmental and Climate Technologies 24:221-230. 10.2478/rtuect-2020-0068

Jason AC. 1974. Thawing frozen fish. Aberdeen: Ministry of Agriculture, Fisheries and Food, Torry Research Station.

Jennings S, Kaiser MJ, and Reynolds JD. 2001. Marine Fisheries Ecology. Malden, MA: Blackwell Publishing. 
1222 Jensen KH, and Sørensen OJ. 2016. The global value chain as a strategic management tool: an

1223

1224

1225

1226

1227

1228

1229

1230

1231

1232

1233

1234

1235

1236

1237

1238

1239

1240

1241

1242

1243

1244

1245

1246

1247

1248

1249

1250

1251

1252

1253

1254

1255

1256

1257

1258

1259

1260

1261

1262

1263

1264

1265

1266 empirical case study from the frozen seafood industry. American Society of Business and Behavioral Sciences. San Diego: ASBBS Proceedings. p 263-278.

Jensen L, Nielsen J, Jørgensen BM, and Frosch S. 2010. Cod and rainbow trout as freeze-chilled meal elements. Journal of the Science of Food and Agriculture 90:376-384. $10.1002 /$ jsfa. 3823

Jessen F, Nielsen J, and Larsen E. 2014. Chilling and freezing of fish. In: Boziaris IS, and Boziaris IS, eds. Seafood Processing: Technology, Quality and Safety. Chichester, UK: Wiley \& Sons, 33-59.

Johnston WA, Nicholson FJ, Roger A, and Stroud GD. 1994. Freezing and refrigerated storage in fisheries. Rome: Food and Agriculture Organization of the United Nations.

Kaloyereas S. 1950. On the history of food preservation. The Scientific Monthly 71:422-424.

Kaplinsky R. 2004. Spreading the gains from globalization: What can be learned from valuechain analysis? Problems of Economic Transition 47:74-115.

Karthikeyan JS, Desai KM, Salvi D, Bruins R, and Karwe MV. 2015. Effect of temperature abuse on frozen army rations. Part 1: Developing a heat transfer numerical model based on thermo-physical properties of food. Food Research International 76:595-604. 10.1016/j.foodres.2015.07.007

Karube I, Matsuoka H, Suzuki S, Watanabe E, and Toyama K. 1984. Determination of fish freshness with an enzyme sensor system. Journal of Agricultural and Food Chemistry 32:314-319. 10.1021/jf00122a034

Khan BM, and Liu Y. 2019. Marine mollusks: Food with benefits. Comprehensive Reviews in Food Science and Food Safety 18:548-564.

Klinkhardt M. 2013. Thaw frozen fish faster and retain quality. Eurofish Magazine 2013:45-48.

Knútsson Ö, Kristófersson DM, and Gestsson H. 2016. The effects of fisheries management on the Icelandic demersal fish value chain. Marine Policy 63:172-179. 10.1016/j.marpol.2015.03.015

Kolanowski W, Jaworska D, and Weißbrodt J. 2007. Importance of instrumental and sensory analysis in the assessment of oxidative deterioration of omega-3 long-chain polyunsaturated fatty acid-rich foods. Journal of the Science of Food and Agriculture 87:181-191.

Kolbe E, and Kramer DE. 2007. Planning for seafood freezing. Fairbanks, Alaska: Alaska Sea Grant College Program, University of Alaska Fairbanks.

Laguerre O, and Flick D. 2004. Heat transfer by natural convection in domestic refrigerators. Journal of Food Engineering 62:79-88. 10.1016/S0260-8774(03)00173-0

Lakshmanan PT. 2000. Fish spoilage and quality assessment. In: Gopalakrishna Iyer TS, and al. e, editors. Proceedings on the Symposium on Quality Assurance in Seafood Processing. Cochin, India: Society of Fisheries Technologists. p 26-40.

Lauzon HL, Margeirsson B, Sveinsdóttir K, Gudjónsdóttir M, Karlsdóttir MG, and Martinsdóttir E. 2010. Overview on fish quality research-Impact of fish handling, processing, storage and logistics on fish quality deterioration. Iceland: Skýrsla Ágrip Matís ohf.

Leygonie C, Britz TJ, and Hoffman LC. 2012. Impact of freezing and thawing on the quality of meat: Review. Meat science 91:93-98. 10.1016/j.meatsci.2012.01.013

Li B, and Sun DW. 2002. Novel methods for rapid freezing and thawing of foods - a review. Journal of Food Engineering 54:175-182. 
1267 Lorentzen G, Lian F, Røhme AA, Johannessen E, Grastveit KV, Grip AE, and Siikavuopio SI.

1268

1269

1270

1271

1272

1273

1274

1275

1276

1277

1278

1279

1280

1281

1282

1283

1284

1285

1286

1287

1288

1289

1290

1291

1292

1293

1294

1295

1296

1297

1298

1299

1300

1301

1302

1303

1304

1305

1306

1307

1308

1309

1310

1311
2019. Effect of freezing-thawing on weight loss, melanosis, and microbial growth in mildly cooked snow crab (Chionoecetes opilio) clusters. LWT - Food Science and Technology 108:283-288. 10.1016/j.lwt.2019.03.083

Mai N, Nguyen D, and Nguyen N. 2020. Influence of frozen storage time and thawing methods on the microflora of thawed Nile tilapia fillets. IOP Conf Ser: Earth Environ Sci. Penang, Malaysia: IOP Publishing. p 12011.

McGill AS, Hardy R, Burt JR, and Gunstone FD. 1974. Hept-cis-4-enal and its contribution to the off-flavour in cold stored cod. Journal of the Science of Food and Agriculture 25:1477-1489.

McGill AS, Hardy R, and Gunstone FD. 1977. Further analysis of the volatile components of frozen cold stored cod and the influence of these on flavour. Journal of the Science of Food and Agriculture 28:200-205.

Min S-G, Hong G-P, Chun J-Y, and Park SH. 2016. Pressure Ohmic Thawing: a Feasible Approach for the Rapid Thawing of Frozen Meat and Its Effects on Quality Attributes. Food and bioprocess technology 9:564-575. 10.1007/s11947-015-1652-3

Montgomerie M. 2015. Basic Fishing Methods. Edinburgh: Seafish. p 103.

Mousakhani-Ganjeh A, Hamdami N, and Soltanizadeh N. 2015. Impact of high voltage electric field thawing on the quality of frozen tuna fish (Thunnus albacares). Journal of Food Engineering 156:39-44. 10.1016/j.jfoodeng.2015.02.004

Nakazawa N, and Okazaki E. 2020. Recent research on factors influencing the quality of frozen seafood. Fisheries science 86:231-244. 10.1007/s12562-020-01402-8

Narwankar S, Flimlin G, Schaffner D, Tepper B, and Karwe M. 2011. Microbial Safety and Consumer Acceptability of High-Pressure Processed Hard Clams (Mercenaria mercenaria). Journal of Food Science:M375.

Nathanailides C, Panopoulos S, Kakali F, Karipoglou C, and Lenas D. 2011. Antemortem and postmortem biochemistry, drip loss and lipid oxidation of European sea bass muscle tissue. Procedia Food Science 1:1099-1104.

National Marine Fisheries Service. 2017. Fisheries of the United States, 2016 Report. In: Commerce USDo, editor. Silver Spring, MD: U.S. Department of Commerce, NOAA Current Fishery Statistics No. 2016. p 176.

Newcombe CL. 1944. The Nutritional Value of Seafoods. In: Virginia Fisheries Laboratory, editor. Educational Series. Educational series (Virginia Fisheries Laboratory); no. 2. Virginia Institute of Marine Science, College of William and Mary. p 17.

NL-GIDC. 2017. 2017 Northern Cod Stewardship Fishery Management Plan Proposal. In: FFAW, editor. St. John's, NL.

Norsworthy P. 2015. NL Seafood Value Chain Infrastructure Benchmarking Assessment. In: Aquaculture DoFa, editor. Hammonds Plains, NS: Pisces Consulting Limited. p 157.

Olafsdóttir G, Lauzon HL, Martinsdóttir E, Oehlenschláuger J, and Kristbergsson K. 2006. Evaluation of shelfl life of superchilled cod (Gadus morhua) fillets and the influence of temperature fluctuations during storage on microbial and chemical quality indicators. Journal of Food Science 71:S97-S109. 10.1111/j.1365-2621.2006.tb08928.x

Otero L, Rodríguez AC, Pérez-Mateos M, and Sanz PD. 2016. Effects of Magnetic Fields on Freezing: Application to Biological Products. Comprehensive Reviews in Food Science and Food Safety 15:646-667. 10.1111/1541-4337.12202 
1312 Papuc C, Goran GV, Predescu CN, and Nicorescu V. 2017. Mechanisms of oxidative processes

1313

1314

1315

1316

1317

1318

1319

1320

1321

1322

1323

1324

1325

1326

1327

1328

1329

1330

1331

1332

1333

1334

1335

1336

1337

1338

1339

1340

1341

1342

1343

1344

1345

1346

1347

1348

1349

1350

1351

1352

1353

1354

1355

1356 in meat and toxicity induced by postprandial degradation products: a review. Comprehensive Reviews in Food Science and Food Safety 16:96-123.

Persson PO, and Löndahl G. 1993. Freezing technology. In: Mallett CP, ed. Frozen Food Technology. New York, NY: Blackie Academic and Professional, 20-58.

Peters JA, Slavin JW, Lane JP, Maccallum WA, Laishley EJ, Dyer WJ, Idler DR, and Fraser DI. 1968. Effect of Stage of Rigor and of Freezing-Thawing Processes On Storage Quality of Refrozen Cod. Journal of the Fisheries Research Board of Canada 25:299-320. 10.1139/f68-025

Phyne J, Hovgaard G, and Hansen G. 2006. Norwegian salmon goes to market: The case of the Austevoll seafood cluster. Journal of Rural Studies 22:190-204. 10.1016/j.jrurstud.2005.08.011

PrimeFish. 2017. Value Chain Input-Output Structure. Stirling, UK: European Union Horizon 2020 Research and Innovation Program. p 144.

Ragnarsson SÖ, and Viðarsson JR. 2017. Overview of available methods for thawing seafood. Reykjavík: Skýrsla Matís-Food Research, Innovation \& Safety.

Regenstein JM, and Regenstein CE. 1991. Introduction to fish technology. New York: New York : Van Nostrand Reinhold.

Rehbein H. 2002. Measuring the shelf-life of frozen fish. In: Bremner HA, ed. Safety and Quality Issues in Fish Processing. Boca Raton, FL: CRC Press, 407-424.

Reid DS. 1993. Basic physical phenomena in the freezing and thawing of plant and animal tissue. In: Mallett CP, ed. Frozen Food Technology. New York, NY: Blackie Academic and Professional, 1-19.

Roiha IS, Jónsson A, Backi CJ, Lunestad BT, and Karlsdóttir MG. 2018a. A comparative study of quality and safety of Atlantic cod (Gadus morhua) fillets during cold storage, as affected by different thawing methods of pre-rigor frozen headed and gutted fish. Journal of the Science of Food and Agriculture 98:400-409.

Roiha IS, Tveit GM, Backi CJ, Jónsson A, Karlsdóttir MG, and Lunestad BT. 2018b. Effects of controlled thawing media temperatures on quality and safety of pre-rigor frozen Atlantic cod (Gadus morhua). LWT-Food Science and Technology 90:138-144.

Rouillé J, Lebail A, Ramaswamy HS, and Leclerc L. 2002. High pressure thawing of fish and shellfish. Journal of Food Engineering 53:83-88. https://doi.org/10.1016/S0260$\underline{\text { 8774(01)00143-1 }}$

Rubio-Celorio M, Garcia-Gil N, Gou P, Arnau J, and Fulladosa E. 2015. Effect of temperature, high pressure and freezing/thawing of dry-cured ham slices on dielectric time domain reflectometry response. Meat science 100:91-96. 10.1016/j.meatsci.2014.10.005

Sackton J. 2014. Newfoundland fisheries in a global market. Available at https://www.seafoodnews.com/ (accessed October 20 2019).

Secci G, and Parisi G. 2016. From farm to fork: lipid oxidation in fish products. A review. Italian Journal of Animal Science 15:124-136. 10.1080/1828051X.2015.1128687

Seremeti MM. 2007. Evaluation of The Quality of Individual Quick Frozen Fish Products (Doctoral Thesis). Robert Gordon University.

Sherstneva A. 2013. Snow crab (Chionoecetes opilio) in the Barents Sea. Possibility of harvesting a new species by the Russian fleet (Master's Thesis). The Arctic University of Norway. 
1357 Sigurgisladottir S, Ingvarsdottir H, Torrissen OJ, Cardinal M, and Hafsteinsson H. 2000. Effects

1358

1359

1360

1361

1362

1363

1364

1365

1366

1367

1368

1369

1370

1371

1372

1373

1374

1375

1376

1377

1378

1379

1380

1381

1382

1383

1384

1385

1386

1387

1388

1389

1390

1391

1392

1393

1394

1395

1396

1397

1398

1399

1400

1401 of freezing/thawing on the microstructure and the texture of smoked Atlantic salmon (Salmo salar). Food Research International 33:857-865. 10.1016/S0963-9969(00)001058

Singh RP, and Heldman DR. 2009. Introduction to Food Engineering. London: Elsevier.

Sirot V, Oseredczuk M, Bemrah-Aouachria N, Volatier JL, and Leblanc JC. 2008. Lipid and fatty acid composition of fish and seafood consumed in France: CALIPSO study. Journal of food composition and analysis 21:8-16.

Steneck RS, Hughes TP, Cinner JE, Adger WN, Arnold SN, Berkes F, Boudreau SA, Brown K, Folke C, Gunderson L, Olsson P, Scheffer M, Stephenson E, Walker B, Wilson J, and Worm B. 2011. Creation of a gilded trap by the high economic value of the Maine lobster fishery. Conservation Biology 25:904-912. 10.1111/j.1523-1739.2011.01717.x

Stringer C, Simmons G, and Rees E. 2011. Shifting post production patterns: Exploring changes in New Zealand's seafood processing industry. New Zealand Geographer 67:161-173.

Suh S, Kim YE, Shin D, and Ko S. 2017. Effect of frozen-storage period on quality of American sirloin and mackerel (Scomber japonicus). Food Science and Biotechnology 26:10771084.

Surette M, Gill T, and LeBlanc P. 1988. Biochemical basis of post-mortem nucleotide catabolism in cod (Gadus morhua) and its relationship to spoilage. Journal of Agricultural and Food Chemistry 36:19-22.

Svendsen ES, Widell KN, Tveit GM, Nordtvedt TS, Uglem S, Standal I, and Greiff K. 2022. Industrial methods of freezing, thawing and subsequent chilled storage of whitefish. Journal of Food Engineering 315. 10.1016/j.jfoodeng.2021.110803

Tironi V, de Lamballerie M, and Le-Bail A. 2010. Quality changes during the frozen storage of sea bass (Dicentrarchus labrax) muscle after pressure shift freezing and pressure assisted thawing. Innovative Food Science and Emerging Technologies 11:565-573. 10.1016/j.ifset.2010.05.001

Tolstorebrov I, Eikevik TM, and Bantle M. 2016. Effect of low and ultra-low temperature applications during freezing and frozen storage on quality parameters for fish. International Journal of Refrigeration 63:37-47. 10.1016/j.jjrefrig.2015.11.003

Tolstorebrov I, Eikevik TM, and Indergård E. 2014. The influence of long-term storage, temperature and type of packaging materials on the lipid oxidation and flesh color of frozen Atlantic herring fillets (Clupea harengus). International Journal of Refrigeration 40:122-130. 10.1016/j.jijrefrig.2013.11.014

Tonkovitch A. 2017. Marketing and the Alaskan pollock industry. In: CCFI, editor. Cod: Building a Fishery of the Future Workshop. Gander, NL.

Torry Research Station. 1977. Quick freezing of fish. Aberdeen: Ministry of Agriculture, Fisheries and Food, Torry Research Station.

Trondsen T. 2012. Value chains, business conventions, and market adaptation: A comparative analysis of Norwegian and Icelandic fish exports. Canadian Geographer:459.

Tull A. 1996. Food spoilage. Food and Nutrition. 3rd ed. ed. Oxford; New York: Oxford University Press, 154-162.

Vaclavik VA, and Christian EW. 2014. Essentials of Food Science. New York, NY: Springer.

Verge R. 2017. Shellfish to groundfish - the economic challenge. In: CCFI, editor. Cod: Building a Fishery of the Future Workshop. Gander, NL. 
1402 Warrier S, Gore M, and Kumta U. 1975. Fish muscle structural proteins. Fishery Technology 1403 12:1-15.

Washburn KE, Stormo SK, Skjelvareid MH, and Heia K. 2017. Non-invasive assessment of packaged cod freeze-thaw history by hyperspectral imaging. Journal of Food Engineering 205:64-73.

Wen X, Hu R, Zhao J-H, Peng Y, and Ni Y-Y. 2015. Evaluation of the effects of different thawing methods on texture, colour and ascorbic acid retention of frozen hami melon (Cucumis melo var. saccharinus). International Journal of Food Science \& Technology 50:1116-1122. 10.1111/ijfs. 12755

Wijsman JWM, Troost K, Fang J, and Roncarati A. 2019. Global Production of Marine Bivalves. Trends and Challenges. In: Smaal A, Ferreira J, Grant J, Petersen J, and Strand Ø, eds. Goods and Services of Marine Bivalves. Cham, Switzerland: Springer International Publishing, 7-26.

Witter A, and Stoll J. 2017. Participation and resistance: Alternative seafood marketing in a neoliberal era. Marine Policy 80:130-140. 10.1016/j.marpol.2016.09.023

Wu X, Zhang M, Adhikari B, and Sun J. 2017. Recent developments in novel freezing and thawing technologies applied to foods. Critical Reviews in Food Science and Nutrition 57:3620-3631.

Yao W, Qin W, Hirasaka K, Hara K, Taniyama S, and Tachibana K. 2019. Relationship between the characteristics of rigor-mortis-related actomyosin and muscle fiber types in the ordinary muscle of various fishes. Journal of the Science of Food and Agriculture 99:6042-6048. 10.1002/jsfa.9880

Zhong Y, Khan MA, and Shahidi F. 2007. Compositional characteristics and antioxidant properties of fresh and processed sea cucumber (Cucumaria frondosa). Journal of Agricultural and Food Chemistry 55:1188-1192. 10.1021/jf063085h

Ziegler F, Winther U, Hognes E, Emanuelsson A, Sund V, and Ellingsen H. 2013. The carbon footprint of Norwegian seafood products on the global seafood market. Journal of Industrial Ecology 17:103-116. 10.1111/j.1530-9290.2012.00485.x 
Table $\mathbf{1}$ (on next page)

Time-temperature effect on spoilage for fish products

Source: (Huss et al., 1995) 


\begin{tabular}{c|ccc}
\hline $\begin{array}{c}\text { Shelf life in days of fish } \\
\text { products stored in ice }\end{array}$ & \multicolumn{3}{|c}{ Shelf life at chill temperatures (days) } \\
\cline { 2 - 4 }$\left(\mathbf{0}^{\circ} \mathbf{C}\right)$ & $5^{\circ} \mathrm{C}$ & $10^{\circ} \mathrm{C}$ & $15^{\circ} \mathrm{C}$ \\
\hline $\mathbf{6}$ & 2.7 & 1.5 & 1 \\
$\mathbf{1 0}$ & 4.4 & 2.5 & 1.6 \\
$\mathbf{1 4}$ & 6.2 & 3.5 & 2.2 \\
$\mathbf{1 8}$ & 8.0 & 4.5 & 2.9 \\
\hline
\end{tabular}

1

2 
Table 2 (on next page)

Phases of cod spoilage

Source: (Huss et al., 1995) 
1

\begin{tabular}{cccc}
\hline Phase & Description & Time & Characteristics \\
\hline I & $\begin{array}{c}\text { Fresh } \\
\text { II }\end{array}$ & $\begin{array}{c}0-2 \text { days } \\
2-6 \text { days }\end{array}$ & $\begin{array}{c}\text { Sweet, seaweedy and delicate taste; can be slightly metallic. } \\
\text { Loss of characteristic taste and odour; no off-flavours. The texture } \\
\text { is still pleasant. }\end{array}$ \\
III & Stale & $6-12$ days & $\begin{array}{c}\text { Spoilage increases during this phase and produces a range of } \\
\text { volatile, unpleasant odours. Trimethylamine (TMA) production } \\
\text { generates the "fishy" smell. } \\
\text { Spoiled and putrid }\end{array}$ \\
IV & Spoiled & $12-15$ days &
\end{tabular}

2 
Table 3 (on next page)

Overview of commercial freezing techniques. 


\begin{tabular}{|c|c|c|c|c|c|}
\hline Evaluation Criteria & Still Freezing & Blast Freezing & Plate Freezing & Immersion Freezing & Cryogenic Freezing \\
\hline Description & $\begin{array}{l}\text { Employs cold, still air } \\
\text { to freeze the product. }\end{array}$ & $\begin{array}{l}\text { Employs cold, forced, } \\
\text { convective air to freeze } \\
\text { the product. }\end{array}$ & $\begin{array}{l}\text { Employs compression } \\
\text { between two chilled } \\
\text { plates to freeze the } \\
\text { product. }\end{array}$ & $\begin{array}{l}\text { Employs immersing the } \\
\text { product in a refrigerated } \\
\text { bath to freeze the } \\
\text { product. }\end{array}$ & $\begin{array}{l}\text { Employs spraying } \\
\text { liquified gas directly } \\
\text { into the freezing cabinet } \\
\text { to freeze the product. }\end{array}$ \\
\hline Typical temperature & -5 to $-30{ }^{\circ} \mathrm{C}$ & -18 to $-30{ }^{\circ} \mathrm{C}$ & -30 to $-50^{\circ} \mathrm{C}$ & -20 to $-55^{\circ} \mathrm{C}$ & $-50^{\circ} \mathrm{C}$ \\
\hline Typical fluid & Natural convection air & Forced convection air & Refrigerant & Brine & Liquified $\mathrm{CO} 2$ or $\mathrm{N} 2$ \\
\hline $\begin{array}{l}\text { Relative heat transfer } \\
\text { coefficient }\end{array}$ & $\mathrm{U}=5.7 \mathrm{~W} \cdot \mathrm{m}-2 \cdot \mathrm{K}-1$ & $\begin{array}{l}\mathrm{U}=22.7 \text { to } 56.8 \mathrm{~W} \cdot \mathrm{m}- \\
2 \cdot \mathrm{K}-1\end{array}$ & $\begin{array}{l}\mathrm{U}=56.8 \text { to } 600 \mathrm{~W} \cdot \mathrm{m}- \\
2 \cdot \mathrm{K}-1\end{array}$ & $\begin{array}{l}\mathrm{U}=210 \text { to } 290 \mathrm{~W} \cdot \mathrm{m}- \\
2 \cdot \mathrm{K}-1 \text { without } \\
\text { convection and } \mathrm{U}=680 \\
\text { to } 740 \mathrm{~W} \cdot \mathrm{m}-2 \cdot \mathrm{K}-1 \text { with } \\
\text { forced convection }\end{array}$ & $\mathrm{U}=1500 \mathrm{~W} \cdot \mathrm{m}-2 \cdot \mathrm{K}-1$ \\
\hline Merits & $\begin{array}{l}\text { - Cold storage and } \\
\text { transportation of frozen } \\
\text { products } \\
\text { - Does not require } \\
\text { uniform product size } \\
\text { and shape }\end{array}$ & $\begin{array}{l}\text { - Highspeed freezer } \\
\text { - Does not require } \\
\text { uniform product size } \\
\text { and shape } \\
\text { - Used in batch, semi- } \\
\text { batch and continuous } \\
\text { processes } \\
\text { - Can produce IQF } \\
\text { product } \\
\text { - Air-impingement } \\
\text { freezers have similar } \\
\text { capabilities to } \\
\text { cryogenic freezers at a } \\
\text { lower cost. }\end{array}$ & $\begin{array}{l}\text { - High cooling rates } \\
\text { - Small footprint } \\
\text { - Low operating costs } \\
\text { - Little product } \\
\text { dehydration }\end{array}$ & $\begin{array}{l}\text { - Very high cooling } \\
\text { rates } \\
\text { - Does not require } \\
\text { uniform product size } \\
\text { and shape } \\
\text { - Efficiency } \\
\text { - Low capital and } \\
\text { operating costs } \\
\text { - Continuous operation }\end{array}$ & $\begin{array}{l}\text { - Ultrahigh cooling } \\
\text { rates and - - Does not } \\
\text { require uniform product } \\
\text { size and shape } \\
\text { - Small footprint } \\
\text { - Lower capital cost } \\
\text { - Continuous operation } \\
\text { - Product is less } \\
\text { susceptible to drip loss } \\
\text { and lipid oxidation }\end{array}$ \\
\hline Detractions & $\begin{array}{l}\text { - Slow cooling rates } \\
\text { - Larger, extracellular } \\
\text { ice crystals } \\
\text { - Increased cellular } \\
\text { damage and drip loss } \\
\text { - Not employed for } \\
\text { commercial freezing } \\
\text { applications } \\
\text { - Used for batch and } \\
\text { semi-batch processes }\end{array}$ & $\begin{array}{l}\text { - Potential for freezer } \\
\text { burn } \\
\text { - Need for regular } \\
\text { defrosting } \\
\text { - Cost of operating } \\
\text { large fans }\end{array}$ & $\begin{array}{l}\text { - Lack of versatility } \\
\text { - Needs uniform size } \\
\text { and shape } \\
\text { - Ice buildup on plates } \\
\text { - Product adhering } \\
\text { - Difficult to fully } \\
\text { automate }\end{array}$ & $\begin{array}{l}\text { - Possible off-flavours } \\
\text { - Corrosion } \\
\text { - Viscosity of cold } \\
\text { refrigerant } \\
\text { - Potential toxicity of } \\
\text { some refrigerants }\end{array}$ & $\begin{array}{l}\text { - Operational cost } \\
\text { - Availability of } \\
\text { liquified gasses } \\
\text { - Risk of Freeze- } \\
\text { cracking } \\
\text { - CO2 is a greenhouse } \\
\text { gas }\end{array}$ \\
\hline Cost & Lowest cost freezer & $\begin{array}{l}\text { More expensive to } \\
\text { purchase and operate } \\
\text { than a still freezer }\end{array}$ & Low operating costs. & $\begin{array}{l}\text { Low capital and } \\
\text { operating cost }\end{array}$ & $\begin{array}{l}\text { Low capital cost. High } \\
\text { operating cost. }\end{array}$ \\
\hline References & (Boonsumrej et al. & h et al. 2007; & (Backi 2015; Dempsey & (Backi 2015; FAO \& & (Backi 2015; \\
\hline
\end{tabular}


2007; Dempsey \& Bansal 2012; Fellows

2016; Jessen et al

2013; Kolbe \& Kramer

2007; Laguerre \& Flick

2004; Norsworthy

2015; Singh \&

Heldman 2009; Suh et

al. 2017)
Backi 2015; Backi 2018; Boonsumrej et al.

2007; Cheng et al.

2014; Dempsey \&

Bansal 2012; Fellows

2016; Garthwaite 1997;

Jessen et al. 2013;

Johnston et al. 1994;

Kolbe \& Kramer 2007;

Seremeti 2007; Suh et
\& Bansal 2012; Fellows WHO 1980; Fellows 2016; Johnston et al. 1994; Kolbe \& Kramer

ohnston et al. 1994;

Kolbe \& Kramer 2007;

Seremeti 2007; Torry

2007; Seremeti 2007;

Singh \& Heldman

2009)

Vaclavik \& Christian

2014)
Boonsumrej et al. 2007;

Espinoza Rodezno et al

2013; Fellows 2016;

Jessen et al. 2013;

Johnston et al. 1994;

Kolbe \& Kramer 2007;

Seremeti 2007) 
Table 4 (on next page)

Overview of commercial thawing techniques. 


\begin{tabular}{|c|c|c|c|c|c|}
\hline $\begin{array}{l}\text { Evaluation } \\
\text { Criteria }\end{array}$ & Still air thawing & Air blast thawing & $\begin{array}{l}\text { Thawing in humidified } \\
\text { air }\end{array}$ & Immersion thawing & $\begin{array}{l}\text { Ultrahigh pressure } \\
\text { thawing }\end{array}$ \\
\hline Description & $\begin{array}{l}\text { Employs natural } \\
\text { convection and } \\
\text { conduction to thaw. }\end{array}$ & $\begin{array}{l}\text { Employs forced } \\
\text { convection and } \\
\text { conduction to improve } \\
\text { thawing rates. }\end{array}$ & $\begin{array}{l}\text { Employs forced } \\
\text { convection of heated and } \\
\text { humidified air to } \\
\text { improve thawing rates. }\end{array}$ & $\begin{array}{l}\text { Employs a bath of } \\
\text { running water to thaw } \\
\text { product more quickly. } \\
\text { Aerating the water can } \\
\text { improve thawing. }\end{array}$ & $\begin{array}{l}\text { Employs a water bath } \\
\text { under ultrahigh pressure } \\
(\sim 210 \mathrm{MPa}) \text { and allowed } \\
\text { to thaw more rapidly } \\
\text { and at lower } \\
\text { temperatures. }\end{array}$ \\
\hline Thawing rate & $10 \mathrm{~mm} \cdot \mathrm{h}-1$ at $15^{\circ} \mathrm{C}$ & & $\begin{array}{l}25 \mathrm{~mm} \cdot \mathrm{h}-1 \text { at } 20^{\circ} \mathrm{C} \text { and } \\
8 \mathrm{~m} \cdot \mathrm{s}-1\end{array}$ & $25-34 \mathrm{~mm} \cdot \mathrm{h}-1$ at $15.5^{\circ} \mathrm{C}$ & $\begin{array}{l}<100 \mathrm{~mm} \cdot \mathrm{h}-1 \text { at } 10^{\circ} \mathrm{C} \\
\text { and } 200 \mathrm{MPa}\end{array}$ \\
\hline Merits & $\begin{array}{l}\text { - Is simple to set up. } \\
\text { - No expensive } \\
\text { equipment to purchase. } \\
\text { - Using racks improved } \\
\text { air circulation and } \\
\text { thawing rate. }\end{array}$ & $\begin{array}{l}\text { - Prevents boundary } \\
\text { layer from forming. } \\
\text { - Improved thawing } \\
\text { rates. }\end{array}$ & $\begin{array}{l}\text { - Efficient thawing. } \\
\text { - Fresh quality, taste, } \\
\text { smell, and appearance of } \\
\text { foods are protected. } \\
\text { - Less drip-loss after } \\
\text { freezing and thawing. } \\
\text { - Potential for } \\
\text { automation. }\end{array}$ & $\begin{array}{l}\text { - Faster than thawing in } \\
\text { air. } \\
\text { - Less yield loss. } \\
\text { - Minimizes lipid } \\
\text { oxidation. }\end{array}$ & $\begin{array}{l}\text { - High heat transfer } \\
\text { rates. } \\
\text { - Better water holding } \\
\text { capacity. } \\
\text { - Less drip loss }\end{array}$ \\
\hline Detractions & $\begin{array}{l}\text { - Slow process. } \\
\text { - Requires ample space. } \\
\text { - Labour-intensive batch } \\
\text { process. } \\
\text { - Product may suffer } \\
\text { from surface } \\
\text { dehydration, lipid } \\
\text { oxidation and growth of } \\
\text { microorganisms. }\end{array}$ & $\begin{array}{l}\text { - Requires ample space. } \\
\text { - Labour-intensive batch } \\
\text { process. } \\
\text { - Additional capital and } \\
\text { operating costs of the } \\
\text { fans. } \\
\text { - Increased maintenance } \\
\text { costs. } \\
\text { - Potential downtime. } \\
\text { - Potential for hotspots. }\end{array}$ & $\begin{array}{l}\text { - Higher capital and } \\
\text { operating costs. } \\
\text { - Higher energy costs. } \\
\text { - Maintenance and } \\
\text { cleaning costs. } \\
\text { - Potential for } \\
\text { overheating the product } \\
\text { surface. } \\
\text { - Inconsistent } \\
\text { programming times. } \\
\text { - required and }\end{array}$ & $\begin{array}{l}\text { - Absorption of water } \\
\text { and loss of flavour. } \\
\text { - Water use and } \\
\text { treatment costs. } \\
\text { - Potential } \\
\text { contamination. } \\
\text { - Potential yield loss. }\end{array}$ & $\begin{array}{l}\text { - Very high capital and } \\
\text { operating costs. } \\
\text { - Significant } \\
\text { maintenance and } \\
\text { potential downtime. } \\
\text { - Possible colour } \\
\text { change. }\end{array}$ \\
\hline Cost & Lowest cost. & $\begin{array}{l}\text { More expensive than } \\
\text { still-air thawing. }\end{array}$ & $\begin{array}{l}\text { Higher capital, } \\
\text { maintenance and } \\
\text { operating costs } \\
\text { compared to air blast } \\
\text { thawing. }\end{array}$ & $\begin{array}{l}\text { Higher cost compared to } \\
\text { thawing in air. }\end{array}$ & Highest cost solution. \\
\hline References & $\begin{array}{l}\text { (Archer et al. 2008; } \\
\text { Backi 2015; Garthwaite } \\
\text { 1999; Haugland 2002; } \\
\text { Jason 1974; Klinkhardt } \\
\text { 2013; Ragnarsson \& } \\
\text { Viðarsson 2017) }\end{array}$ & $\begin{array}{l}\text { (Archer et al. 2008; } \\
\text { Backi 2015; Garthwaite } \\
\text { 1999; Haugland 2002; } \\
\text { Jason 1974; Regenstein } \\
\text { \& Regenstein 1991) }\end{array}$ & $\begin{array}{l}\text { (Archer et al. 2008; } \\
\text { Backi 2015; Coolnova } \\
\text { n.d.; Indzere et al. 2020; } \\
\text { Jason 1974; Ragnarsson } \\
\text { \& Viðarsson 2017) }\end{array}$ & $\begin{array}{l}\text { (Archer et al. 2008; } \\
\text { Backi 2015; Backi 2018; } \\
\text { Gonçalves et al. 2012; } \\
\text { Jason 1974; Regenstein } \\
\text { \& Regenstein 1991) }\end{array}$ & $\begin{array}{l}\text { (Archer et al. 2008; } \\
\text { Backi 2015; Backi 2018; } \\
\text { Cai et al. 2019; } \\
\text { Chevalier et al. 1999; } \\
\text { Indzere et al. 2020; } \\
\text { Ragnarsson \& Viðarsson }\end{array}$ \\
\hline
\end{tabular}


2017; Rouillé et al.

2002; Wu et al. 2017) 


\section{Table 5 (on next page)}

Summary of freezing and thawing commercial North Atlantic seafood species. 


\begin{tabular}{|c|c|c|c|}
\hline & Demersal Species & Pelagic Species & Shellfish Species \\
\hline Habitat & Near Bottom & $\begin{array}{l}\text { Mid to high in the water } \\
\text { column }\end{array}$ & Seafloor \\
\hline Activity Level & Sedentary & Highly active & Inactive \\
\hline $\begin{array}{l}\text { Lipid content in } \\
\text { the flesh }\end{array}$ & Low & High & Varies by species \\
\hline $\begin{array}{l}\text { Merits } \\
\text { freezing }\end{array}$ & $\begin{array}{l}\text { Increased shelf life allows } \\
\text { the product to be shipped to } \\
\text { lower-cost regions for } \\
\text { secondary processing or } \\
\text { larger markets, allows the } \\
\text { product to be held until } \\
\text { demand improves, freezing } \\
\text { before rigour can enhance } \\
\text { product quality. }\end{array}$ & $\begin{array}{l}\text { Increased shelf life allows } \\
\text { the product to be shipped to } \\
\text { lower-cost regions for } \\
\text { secondary processing or } \\
\text { larger markets. }\end{array}$ & $\begin{array}{l}\text { Allows echinoderms to be } \\
\text { shipped to market after } \\
\text { processing, will enable } \\
\text { crustaceans to be cooled } \\
\text { quickly and shipped for } \\
\text { secondary processing or } \\
\text { market. }\end{array}$ \\
\hline $\begin{array}{l}\text { Detractions } \\
\text { freezing }\end{array}$ & $\begin{array}{l}\text { Drip loss, protein } \\
\text { denaturation, lipid oxidation, } \\
\text { and texture changes if the } \\
\text { temperature is not } \\
\text { maintained below }-30^{\circ} \mathrm{C} \text {. }\end{array}$ & $\begin{array}{l}\text { Drip loss, lipid oxidation, } \\
\text { denaturation of proteins, } \\
\text { discolouration of flesh, not } \\
\text { effective for some species } \\
\text { (i.e., capelin, anchovies, and } \\
\text { sardines). }\end{array}$ & $\begin{array}{l}\text { Not effective for mollusks, it } \\
\text { can result in drip loss, } \\
\text { textural changes in } \\
\text { crustaceans due to protein } \\
\text { denaturation, and lipid } \\
\text { oxidation if not adequately } \\
\text { performed. }\end{array}$ \\
\hline
\end{tabular}


Figure 1

Schematic views of freezing: a) Indirect contact freezing systems, and b) direct contact freezing systems

Source: Singh \& Heldman 2009

a)

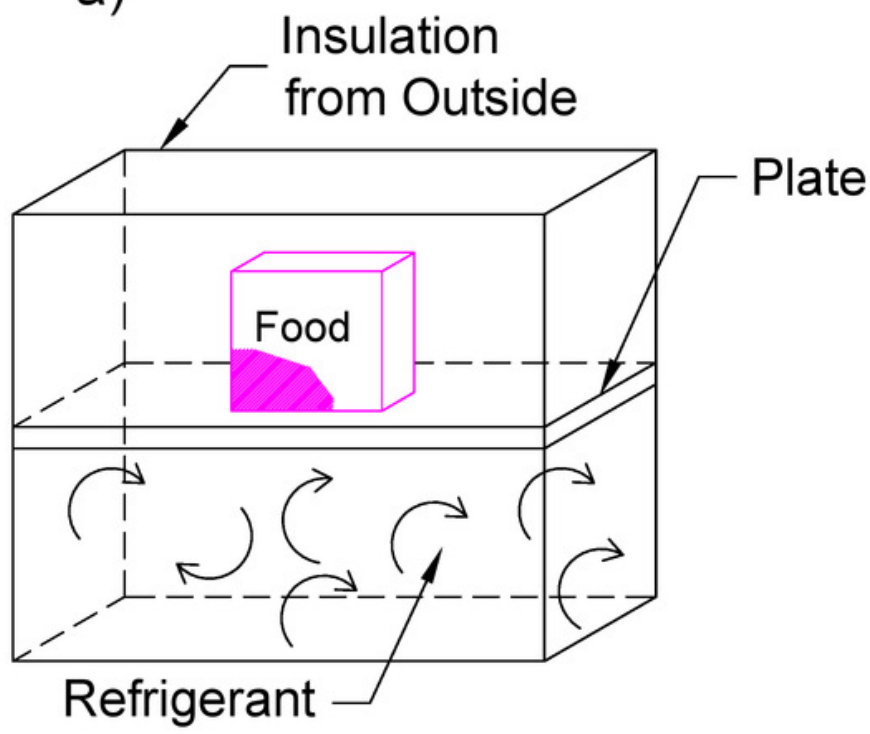

b)

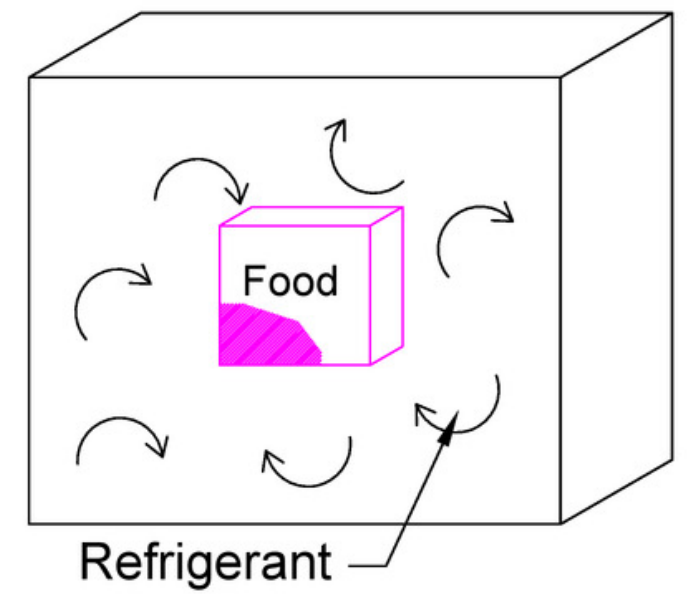


Figure 2

Schematic depiction of freezers: a) Typical batch air blast freezer, and b) Typical continuous tunnel freezer

Source: Dempsey \& Bansal, 2012

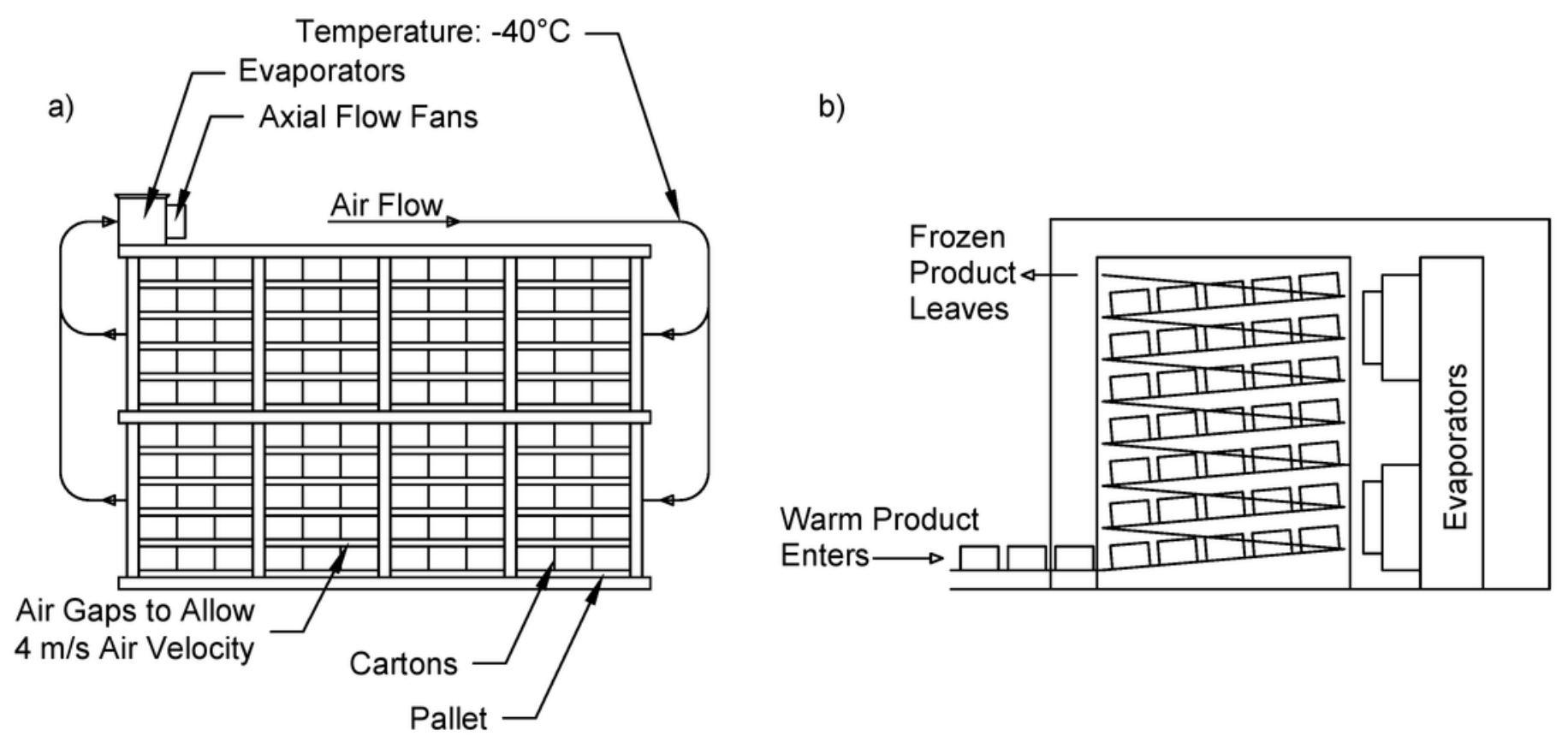




\section{Figure 3}

Examples of freezing systems: a) Still air, b) air blast, c) tunnel, d) horizontal plate, e) cryogenic, $f$ ) brine immersion, $g$ ) vertical plate, and $h$ ) spiral.

Photo credits a), b), and d): Pete Brown

Sketches c), e), f), g), h): Pete Brown

\section{Original photo sources:}

c) https://www.skaginn3x.com/iqf-tunnel-freezer

e) https://www.airgas.com/industries/food-industry/freezing-and-chilling[p]

f) https://www.seafoodprocessingequipment.ca/processing-equipment/brine-freezing-equipment[p]

g) https://www.sf.technology/en/productDetail?id=22719d256cf16c36016cf2a68e24000e[p]

h) https://www.harrydavis.com/equipment-marketplace/praxair-je-u6-nitroshield-spiral-freezer/[p]

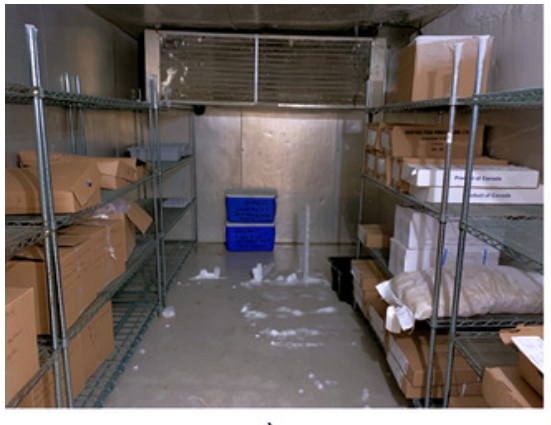

a)

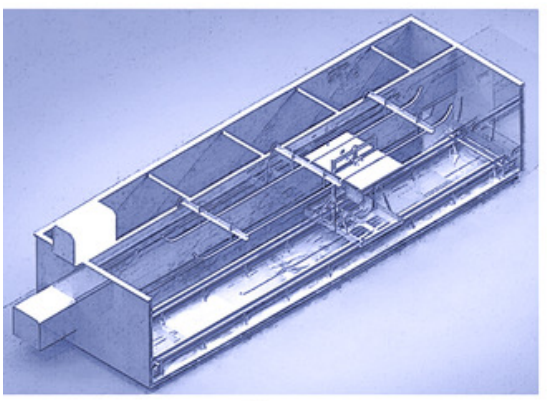

f)

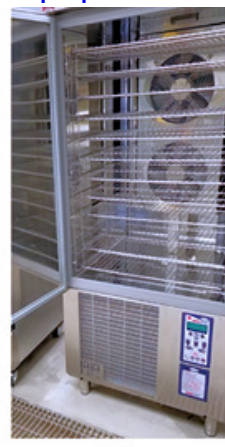

b)

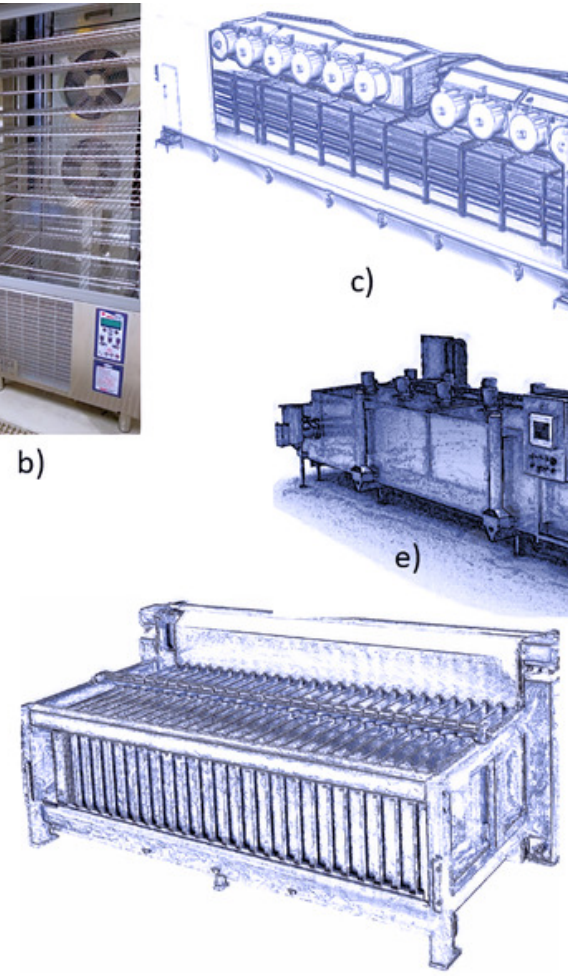

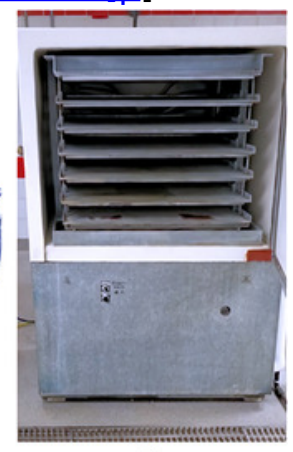

d) g)

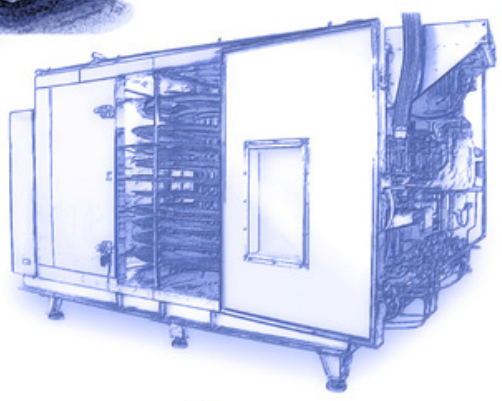

h) 
Figure 4

Number of research articles found in the Web of Science database when searching "fish" and "freezing" vs "fish" and "thawing" published between 2017 and 2021 (conducted on April 2, 2021)

https://apps.webofknowledge.com

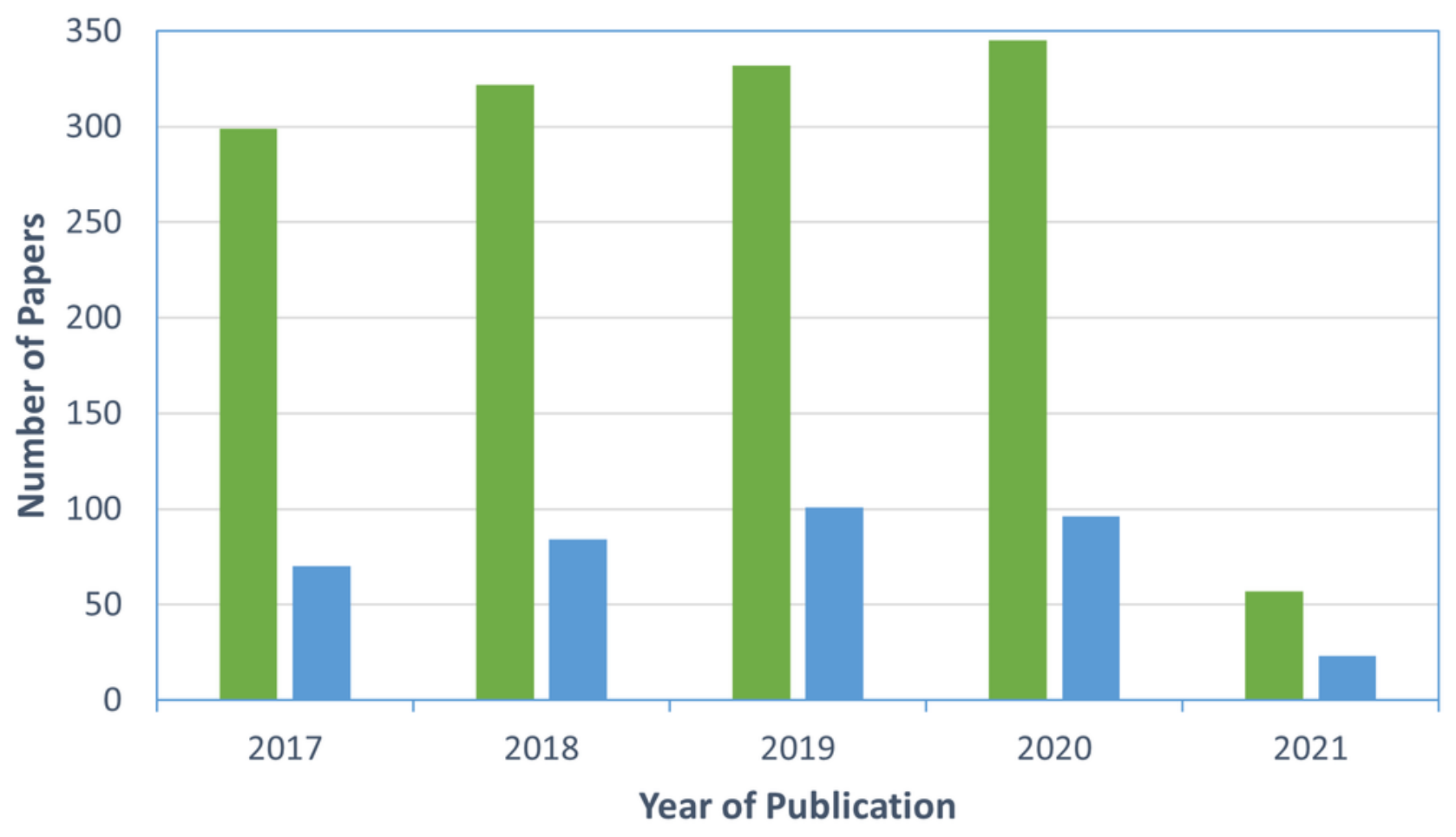

Fish AND Freezing Fish AND Thawing 


\section{Figure 5}

Examples of thawing systems: a) still air, b) air blast, c) warm humidified air, d) still water, e) automated, f) aerated water, $g$ ) high-pressure

Photo credits c), d), and g): Pete Brown

Photo credits a): Klinkhardt 2013

Photo credits f): Backi 2018

Sketches b) and e) by: Pete Brown

\section{Original photo credits:}

b) https://www.kometos.com/finncold

e)

https://equipment7.com/fish-processing-equipment/defrosting/machine-water-defrosting-fish-equipment/[p]

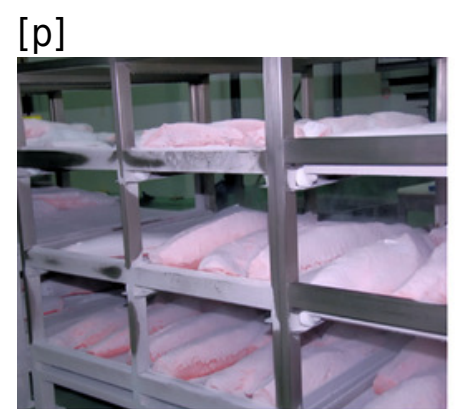

a)

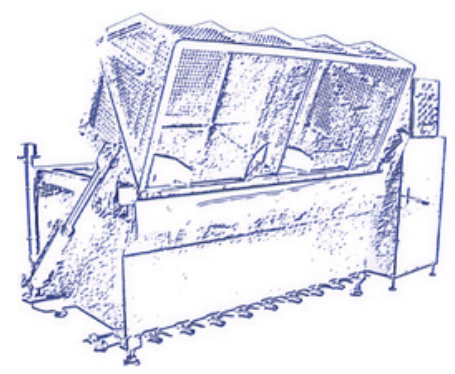

e)

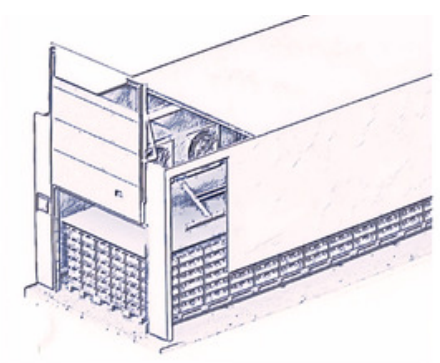

b)

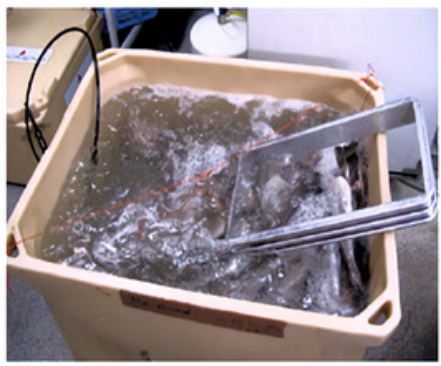

f)

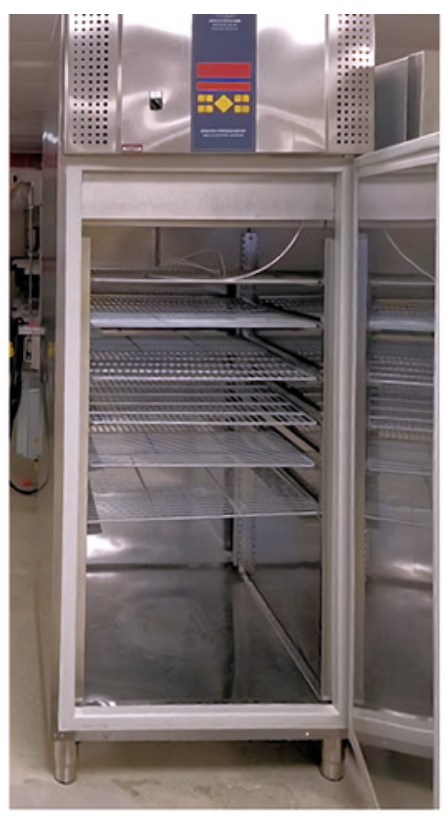

c)

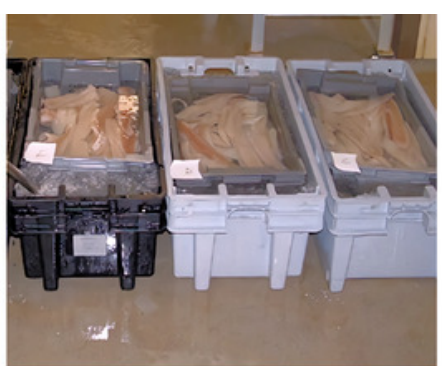

d)

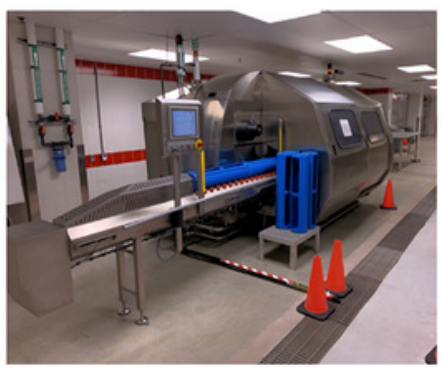

g) 
Figure 6

Temperature - pressure phase diagram for water

Source: Wu et al. 2017

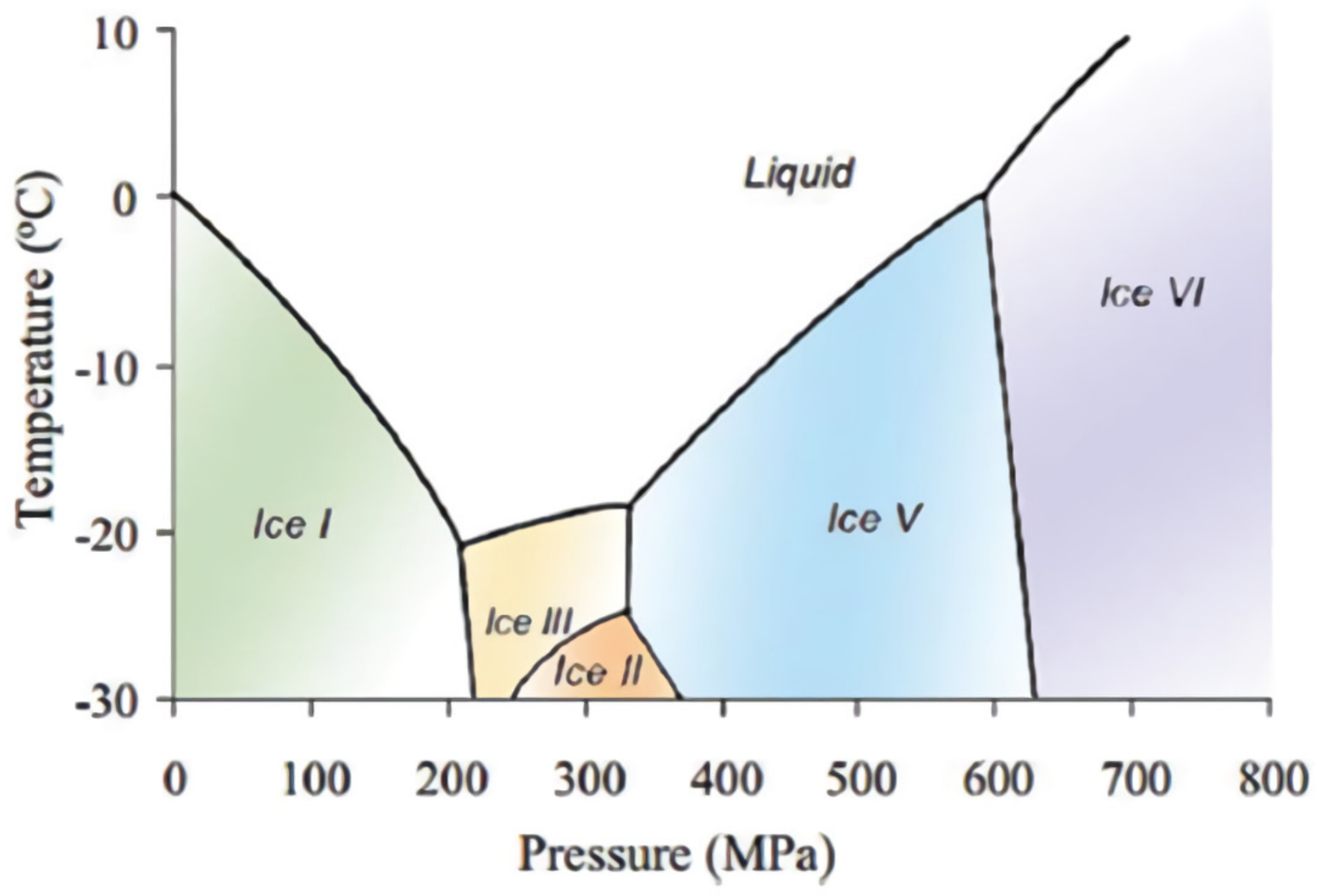


Figure 7

Generalized seafood value chain depicting frozen, processed seafood being sold in a different state, province or country than where it was landed

Source: Knútsson et al. 2016; Witter \& Stoll 2017

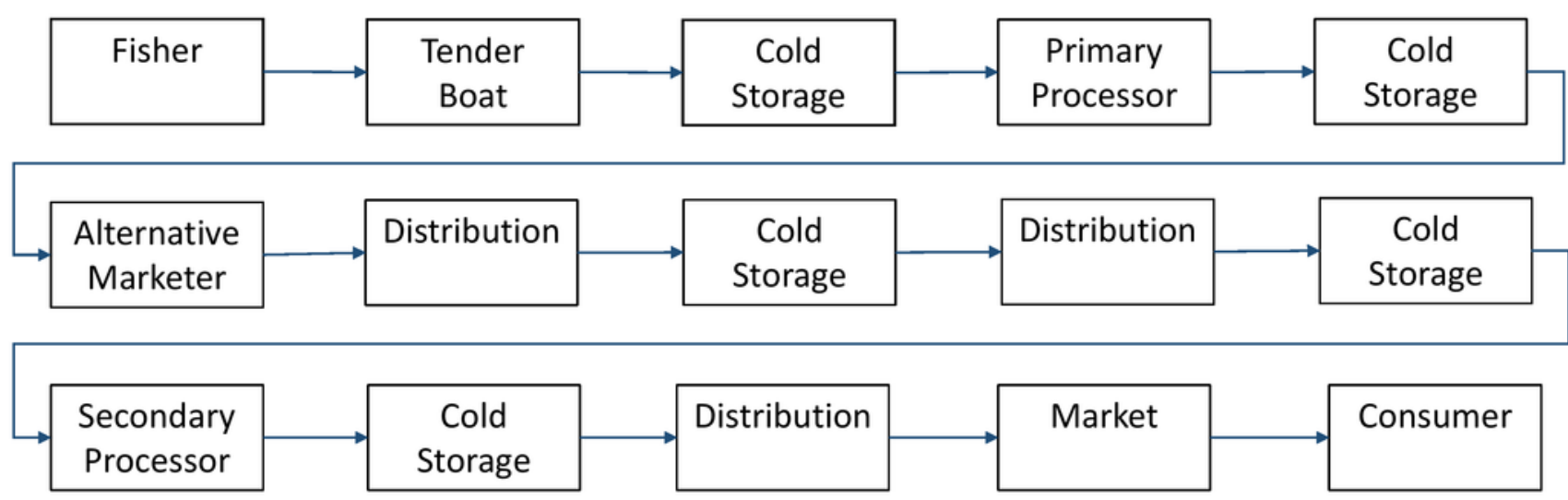


Figure 8

Map of Newfoundland and Labrador NAFO regions

Sources: Becker et al. 2018; Bivand et al. 2021; Bivand \& Lewin-Koh 2021; Hijmans 2021;

Mcllroy et al. 2020; R Core Team 2021; Wickham 2016; https://www.nafo.int/Data/GIS 


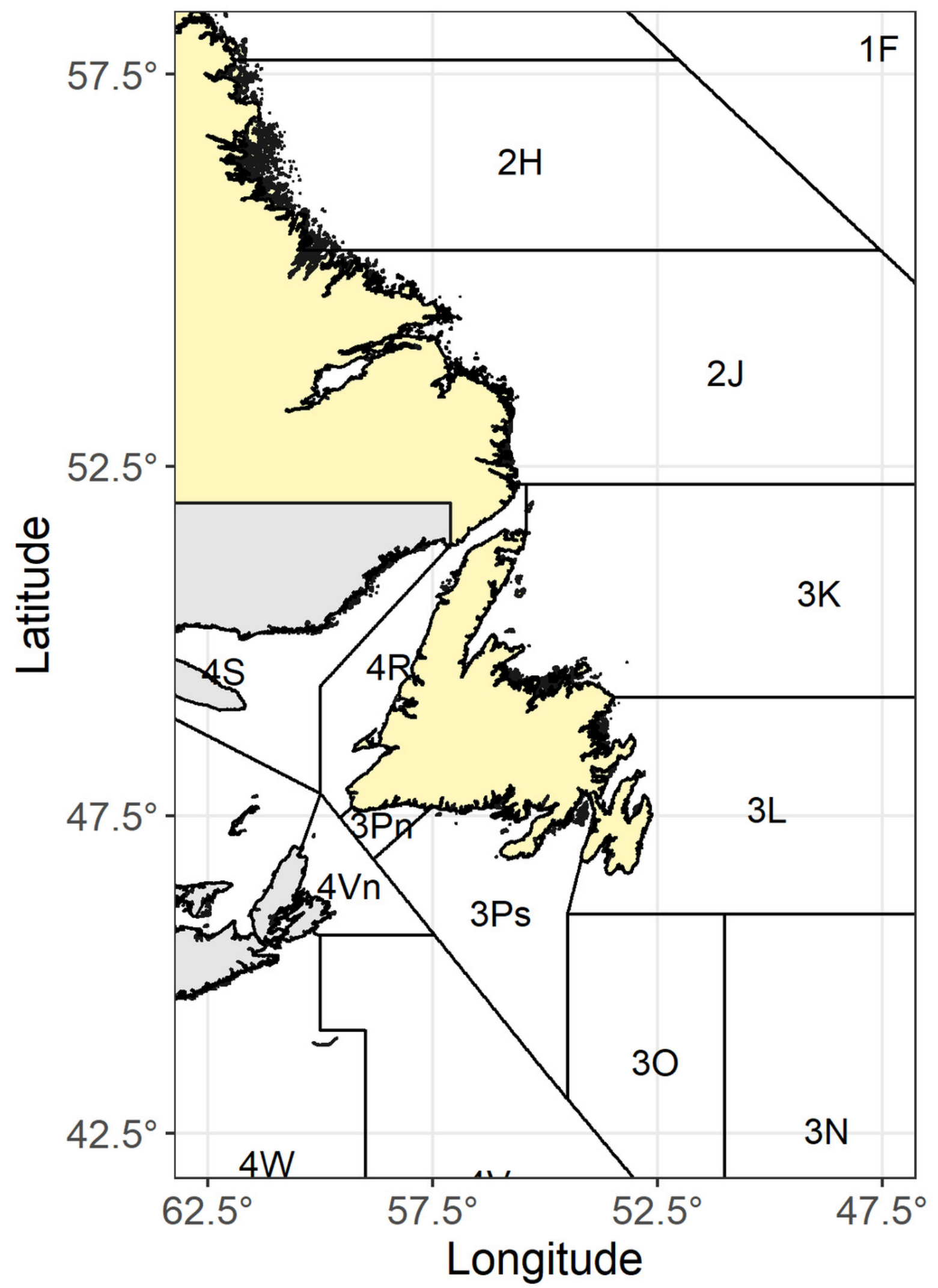


Figure 9

Price ladder for cod products in US\$

Source: Sackton 2014

\section{Cod price ladder}

$\$ 8.50$

$\$ 7.50$

$\$ 6.50$

$\$ 5.50$

$\$ 4.50$

$\$ 3.50$

$\$ 2.50$

$\$ 1.50$

$\$ 0.50$

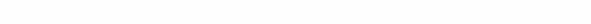

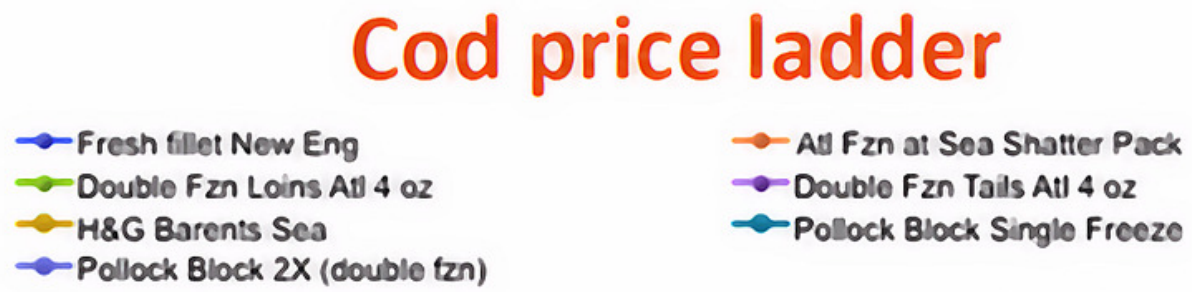

- All Fzn at Soa Shatter Pack

$\rightarrow$ Double Fzn Tails All 402

-Pollock Block Single Freeze 